\title{
Kas İskelet Sistemi Ağrılarında Proloterapi Enjeksiyonları
}

\author{
Prolotherapy Injections for Musculoskeletal Pain
}

\section{Illker Solmaz}

Gülhane Eğitim Araştırma Hastanesi Geleneksel ve Tamamlayıcı Tıp Uygulama Merkezi, Anestezi ve Reanimasyon A.D. Ankara

Yazışma Adresi / Correspondence:

\section{Dr. Öğr. Üyesi İlker Solmaz}

Gülhane Eğitim Araştırma Hastanesi Geleneksel ve Tamamlayıcı Tip Uygulama Merkezi, Anestezi ve Reanimasyon A.D. Ankara, TÜRKiYE

E-mail: doktorilkersolmaz@gmail.com

Orcid

İlker Solmaz: https://orcid.org/0000-0002-1959-8159

Geliş Tarihi / Received : 29-05-2019 Kabul Tarihi / Accepted : 10-07-2019 Yayın Tarihi / Online Published: 30-09-2019

Solmaz İ., Kas İskelet Sistemi Ağrılarında Proloterapi Enjeksiyonları,

J Biotechnol and Strategic Health Res. 2019;3(Özel Sayı):91-114 DOI: bshr.571715

\begin{abstract}
Özet
Proloterapi, az miktarda irritan solüsyonun normal hücre ve doku büyümesini uyarmak amacıyla ağrıll, hasarlı veya dejenere olmuş tendon ve ligamentlerin yapışma bölgelerine (entezis) uygulandığı enjeksiyonları içeren rejeneratif bir tedavi yöntemidir. Bu yöntem kas iskelet sistemi kaynaklı ağrıların tedavisinde 80 yıldan uzun süredir kullanılmaktadır. Proloterapi’nin kas iskelet sistemi sorunlarında kullanımı, ağrının ligamentlerdeki zayıflama sonucu ortaya çıkan relaksasyona bağlı olduğu ve bu ligamentlerin tahriş edici, hücre proliferasyonunu uyarıcı solüsyonların enjeksiyonları ile güçlendirilebileceği düşüncesine dayandırılmaktadır.

Ligament relaksasyonu; genel olarak ligament içeriğindeki liflerin dayanıklılığının bozulduğu durum olarak tanımlanmaktadır. İrritan solüsyonların enjeksiyonları sonrasında tendon ve ligamentlerde fibroblast hiperplazisi, hücre proliferasyonu, kollojen lif çapında artı̧̧ gibi histolojik yapısal değişiklikler gözlenmektedir. Histolojik değișimlerin yanısıra tendon ve ligament gücünde artış da gözlenmektedir. Bu etki, yara iyileşme mekanizmasının tetiklenmesine bağlı oluşmaktadır.

Proloterapi enjeksiyonlarının eklem ağrıları ve eklem laksitesi, kronik bel ağrısı, epikondilit, tendinopatiler, aşırı kullanım yaralanmaları gibi kas iskelet sistemi sorunlarındaki etkinliğini araștıran çalışmaların artması ile birlikte son dönemde bu rejeneratif tedavi yöntemine ilgi giderek artmaktadır.

Anahtar Proloterapi, kas iskelet sistemi ağrısı, tendon, ligament, laksite

Kelimeler

Abstract

Prolotherapy is a regenerative treatment method that involves injections of small amounts of an irritant solution to the site of painful, injured or degenerated tendon and ligament insertions (entheses) to promote growth of normal cells and tissues. It has been used in clinical practice for more than 80 years to treat various musculoskeletal pain. The use of prolotherapy in musculoskeletal problems is based on the idea that pain is due to relaxation caused by attenuation of the ligaments and that these ligaments can be strengthened by injections of irritating, cell proliferation stimulating solutions.

Ligament relaxation; generally described as a condition in which the strength of the ligament fibers has become impaired. Histological structural changes such as fibroblast hyperplasia, cell proliferation, increase in collagen fiber diameter are observed in tendons and ligaments after injections of irritant solutions. In addition to histological changes, increase in tendon and ligament strenght is also observed. This effect is due to triggering of wound healing mechanism.

With the increasing number of studies investigating the efficacy of prolotherapy injections in musculoskeletal problems such as joint pain and joint laxity, chronic low back pain, epicondylitis,
\end{abstract} tendinopathies, and overuse injuries, there is an increasing interest in this regenerative treatment method 


\section{Giriş}

Proloterapi, kas iskelet sistemi hastalıklarının tedavisinde kullanılan, tendon ve ligament enjeksiyonlarını içeren bir tedavi yöntemidir. ${ }^{1}$ Enjeksiyonların yanı sıra egzersiz, vitamin ve mineral gibi besin takviyeleri de sıklıkla destek olarak kullanılmaktadır. Proloterapi'nin kas iskelet sistemi sorunlarında kullanımı, ağrının ligamentlerdeki zayıflamaya bağlı olduğu ve bu ligamentlerin tahriş edici, hücre proliferasyonunu uyarıcı solüsyonların enjeksiyonları ile güçlendirilebileceği düşüncesine dayandırılmaktadır. ${ }^{2}$ Proloterapi enjeksiyonları tipik olarak bağ dokusu disfonksiyonu olan bölgeye veya yakınına uygulanmaktadır.

Bu enjeksiyon tekniği ilk olarak 1937 yılında Louis Schultz tarafından tanımlanmıştır. Shultz ${ }^{3}$, temporomandibular eklemin ağrılı subluksasyonunun eklem aralığına 0.25-0.5 $\mathrm{ml}$ sodyum psyliate enjeksiyonu ile etkili bir şekilde tedavi edildiğini rapor etmiştir.

Sklerozan madde (sodyum psylliate) enjeksiyonu sonrasında bağ dokuda değişimler (fibrozis) olduğu da ilk olarak Louis Schultz tarafından gösterilmiștir. Shultz ${ }^{4}$, sklerozan madde enjeksiyonu sonrası dokularda 4-6 günde yumuşak doku fibrozisi geliştiğini bildirmiştir. Bu bulgu, enjekte edilen sklerozan solüsyonların eklem çevresindeki ve intraartiküler yerleşimli ligamanların ve eklem kapsülünün güçlenmesine neden olarak eklem stabilizasyonunu sağlamakta kullanılabileceği düşüncesini desteklemiştir.

Bu düşünce George S. Hackett tarafından genelleştirilmiştir. Hackett ${ }^{2}$, kronik ağrılı kas iskelet sistemi disabilitesinin sıklıkla ligaman laksitesinden kaynaklandığını ve bu durumun eklem instabilitesine ve bunu takiben ligaman ve tendonlardaki nosiseptif liflerin aktivasyonuna neden olduğunu bildiren görüşünü yayınlamıştır. $\mathrm{Bu}$ görüşe göre zayıflamış ligamanlardan kaynaklı aferent sinyaller kas iskelet sistemi ağrısının belirgin bir kaynağıdır. Hackett, mekanik instabilitenin ligamanlar, eklem kapsülü ve tendonlar üzerinde oluşturduğu anormal ve aşırı internal-eksternal kuvvetlerin nosiseptif uyarının kaynağı olduğunu söylemiştir. Ligaman laksitesinin potansiyel kaynakları fiziksel travma veya anormal postür olabilir ve neden olduğu eklem instabilitesi uzun dönemde dejeneratif değişimlerle sonuçlanabilmektedir.

Doku hasarına bağlı nosiseptör impulslar omurilik arka boynuzuna A-delta veya $\mathrm{C}$ lifleri ile iletilirler. ${ }^{5} \mathrm{Bu}$ lifler lamina I, II, III, IV ve V de sinaps yaparlar. Lateral boynuz hücrelerine iletilen impulslar sempatik otonomik yanıtı başlatırlar. Lateral boynuz hücrelerinden impulslar eferent lifler ile kan damarlarına, ter bezlerine ve kıl foliküllerine taşınmaktadır. Ön boynuz hücrelerine ulaşan aferent liflerse motor yanıtı başlatarak uzun süreli bir kas kontraksiyonuna neden olurlar. Bu kas kontraksiyonu dokuda iskemi gelişmesine katkıda bulunmaktadır. ${ }^{6}$

Mekanik instabiliteye bağlı nosisepsiyonun sekonder doku iskemisine neden olduğu ve bu şekilde duyusal bir kısır döngüye neden olduğu düşünülmektedir. Ayrıca uzamış kas spazmlarının neden olduğu anormal kuvvetlerin tendon veya ligaman laksitesini dolayısı ile de mekanik instabiliteyi daha da arttırabileceği düşünülmektedir.

1953 yılında Hackett ${ }^{7}$, sakroiliak bölgede ağrı yakınması olan 253 hastada posterior sakroiliak ligamanlara uyguladığı sklerozan solüsyon enjeksiyonlarının etkisini incelediği çalışmanın sonuçlarını yayınlamıştır. Hackett bu çalışmanın sonucunda kronik tekrarlayan sakroiliak disabilitenin ligaman instabilitesinden kaynaklandığını bildirmiştir.

Sklerozan solüsyonların enjeksiyonlarına bağlı ligamanlarda oluşan biyokimyasal, histolojik ve mekanik değişimlerin değerlendirildiği birçok çalışma yapılmıştır.

Sklerozan solüsyonların tendonlar üzerindeki "yapısal etkileri” de Hackett tarafından in vivo olarak araştırılmıştır. Hackett tavşanların gastroknemius ve superfisiyal fleksör tendonlarına sylnasol (bir sodyum tuzu yağ asidi) enjekte ettikten sonra belirli aralıklarla ışık mikroskobunda ten- 
donların kesitsel incelemesi yapılmıştır. 48. saatte tendonda ve tendon kılıfında belirgin lenfosit infiltrasyonu gözlenirken, 2. haftada lenfosit infiltrasyonunun azalıp fibröz doku oluştuğu, 9. ay sonunda ise artık histolojik olarak enflamasyon bulgusu olmaksızın kalıcı fibröz dokunun oluştuğu saptanmıştır. 9 ve 12. aylarda tendon kalınlığında \%40 artış ve tendo-ossöz bileşke kalınlığında \%30 artış saptanmıştır. Ayrıca 1 ve 3. aylarda radyografik olarak tendo-ossöz bileşkede kemik yapımında artış olduğu da gözlenmiştir. ${ }^{2}$ Bu çalışma, proliferan solüsyon enjeksiyonu ile ligamanlarda ve kemik-tendon bileşkesinde hipertrofinin geliştiğini gösteren ve bu konuda başlangıç niteliğinde bir çalışma olması nedeniyle oldukça önemlidir.

1983 de Liu ve ark 8 tavşanlar üzerinde yaptıkları bir çalışmada, bir gruba medial kollateral ligamentlerin tibial ve femoral yapışma bölgelerine \%5 sodyum morrhuate enjeksiyonları uygularken, kontrol grubuna aynı miktarda steril izotonik solüsyon enjeksiyonu uygulamışlar ve sonrasında ligament kuvvetini değerlendirmişlerdir. Enjeksiyonlardan sonra Bytrex kuvvet transdüseri ile yapılan değerlendirmede proliferan solüsyon uygulanan grupta kontrol grubuna göre ligament kuvvetinde \%27 daha fazla artış saptanmıştır. Aynı zamanda proliferan solüsyon enjekte edilen grupta kollajen lif çapında da \%56 oranında artış saptanmıştır. Bu çalışma, proloterapi enjeksiyonları uygulanan ligamanlarda kontrol grubuna göre anlamlı yapısal değişiklik olduğunu göstermesi ile birlikte kuvvet artışının da olduğunu ilk kez göstermesi açısından önemli bir çalışmadır.

Maynard ve $\operatorname{ark}^{9}$ sklerozan solüsyon (sodyum morrhuate) enjeksiyonu sonrasında tavşanlarda aşil ve patella tendonlarındaki biyokimyasal ve morfolojik değişimleri araştırdıkları çalışmalarında kontrol grubuna \%3’lük etanol uygulamışlar ve enjeksiyonların (1, 3 ve 5 enjeksiyon) etkilerini 1, 4 ve 9. haftalarda incelemişlerdir. Bu çalışmanın sonucunda çalışma grubunda saptanan tendon çapındaki anlamlı artış Hackett 2 ve Liu’nin 8 daha önceki çalışmalarıyla uyumlu olarak bulunmuştur. Çalışmada tendon ça- pındaki bu artışın 3. ve 5. enjeksiyonlardan sonra küçük kollajen fibrillerindeki, su içeriğindeki, glikozaminoglikan içeriğindeki artışla ve fibroblast hiperplazisi ile ilişkili olduğu saptanmıştır. Bununla birlikte, tek enjeksiyon uygulanan grupta kollajen lifi çapında anlamlı bir değişim veya enflamatuvar hücre infiltrasyonu gözlenmemiştir. Bu bulgu, sklerozan madde uygulamasında doza bağlı yanıtın olduğunu destekler niteliktedir. Önemli bir başka bulgu, kollajen liflerinin uygulamalardan sonra ligaman düzlemine paralel düzende kalmaya devam etmiş olmalarıdır.

Benzer histolojik değişimler Klein ve ark'nın ${ }^{10}$ kronik bel ağrılı hastalar üzerinde yaptıkları çalışmada proliferan solüsyonların enjeksiyonu sonrasında da saptanmıştır. Dekstroz, gliserin ve fenol karışımından oluşan solüsyon posterior sakroiliak ligament yapışma bölgelerine haftada bir kez toplam 6 hafta uygulanmıştır. Tedaviden önce ve 3 ay sonra posterior sakroiliak ligamandan alınan biyopsi örnekleri incelenmiştir. Tedavi sonrasında alınan biyopsi örneklerinde ışık mikroskopisi ile yapılan incelemede fibroblast hiperplazisi gözlemlenirken, elektron mikroskobu ile yapılan incelemede ligaman çapında ortalama \%58'lik artış saptanmıştır.

Bu çalışmalar sklerozan solüsyon enjeksiyonlarının ligaman proliferasyonuna neden olduğu yönünde güçlü kanıtlar sağlamışlardır. Histolojik değerlendirmeler proliferan solüsyonların enjeksiyonları sonrasında enflamasyonun ve bunu takip eden fibroblast proliferasyonunun varlığını göstermektedir.

\section{Tendon ve Ligament Relaksasyonu}

Ligament relaksasyonu; genel olarak ligament içeriğindeki liflerin dayanıklılığının bozulduğu durum olarak tanımlanabilir. ${ }^{2}$

Ligament relaksasyonunun etkileri, ilk olarak 1911 yllında Meisenbach tarafından 84 vaka üzerinde sakroiliak relaksasyonun incelendiği bir çalışmada araştırılmıştır. Bu çalışma sonucunda Meisenbach, pelvik ligamentlerin tonusu 
(gücü) normal olduğunda sakroiliak eklemlerin yüksek gerilim kuvvetlerine karşı koyabildiğini ancak herhangi bir nedenle pelvik ligamentlerde relaksasyon geliştiğinde sakroiliak eklemlerin yaralanmaya yatkın hale geldiklerini belirtmiştir. ${ }^{11}$

Mengert ${ }^{12}$, sakroiliak relaksasyonun antik dönemden bu yana bilinen bir durum olduğunu ve kadınlarda daha sık gözlemlenmekle birlikte erkeklerde daha şiddetli seyrettiğini belirtmiştir. Mengert, ayrıca ligamentlerin eklemin aşırı hareketini önleme fonksiyonu olduğunu, ligament yaralanması oluştuğunda ise çevre kas dokusunun bu ligamenti koruma görevini üstlendiğini ve bunun sonucunda da etkilenen kasın gerginleştiğini ve yorgun düştügünü belirterek o dönem için çok önemli bir saptamada bulunmuştur.

Magnuson $^{13}$, ligament yaralanmasının bel ağrısının en sık nedeni olduğunu ve diğer bölgelere oranla lumbosakral bölgedeki mekanik yaralanmaların ayırıcı tanısının daha önemli olduğunu belirtmiştir. Magnuson, lomber bölgede oluşan ve lumbosakral patolojilere zemin hazırlayan yaralanmaların (strain) öncelikle intervertebral diskte değil de spinal kanalın posterior bölgesinde yer alan ligamentlerde ve eklemlerde geliştiğine ve ayrıca eklemlerin de ligamentlerin kontrolünde olduğuna, bu nedenle opere edilen ve diski alınan hastalarda ağrı yakınmasının devam edebildiğine dikkat çekmiştir. Magnuson'un bu değerlendirmesi Hackett'ın $^{2}$ kronik ağrılı kas iskelet sistemi disabilitesinin sıklıkla ligaman laksitesinden kaynaklandığını ve bu durumun eklem instabilitesine ve bunu takiben ligaman ve tendonlardaki nosiseptif liflerin aktivasyonuna neden olduğunu bildiren görüşüne zemin hazırlayan ve proloterapinin gelişimine önemli oranda katkıda bulunan çalışmalardandir.

Tendonlar, kasları her iki ucundan kemiklere bağlayan ve kas aktivitesi esnasında kasın kemiğe sıkıca bağlantısını sağlayan yapılardır ve ligamentlerde olduğu gibi kemiğe yapışma noktalarında relaksasyon gelişebilmektedir.
Newman ${ }^{14}$, supraspinöz ve interspinöz ligamentlerdeki zayıflı̆̆ın disk prolapsusuna neden olduğunu ve omurga ligamentlerinde meydana gelen yaralanmaların kronik bel ağrısının en sık nedeni olduğunu belirtmiştir. Ayrıca bunun akut bir olay olmadığına uzun bir süreç içinde gerçekleștiğine, ligament relaksasyonuna sekonder gelişen disk herniasyonunun ligament hasarından yıllar sonra ortaya çıktığına dikkat çekmiş ve disk hernisi operasyonları esnasında supraspinöz ligament hasarının ve vertebra instabilitesinin sık gözlemlediği bulgular olduğunu belirtmiştir. Sonrasında O'Connell $\mathrm{de}^{15}$, bel ağrısının ligament yırtıklarıyla ilişkili olduğunu ve bel ağrısında cerrahi seçeneğin ancak konservatif yöntemlerin başarısız olduğu durumlarda gündeme gelmesi gerektiğini belirtmiştir. $\mathrm{Bu}$ değerlendirmeler daha sonra birçok araştırmacı tarafından desteklenmiştir.

Ligament relaksasyonu geliştiğinde, ekleme aşırı düzeyde olmayan bir yüklenme olduğunda ve ligament normal sınırlarda gerildiğinde dahi ağrı oluşmaktadır. Bu ağrı ligament yapisinda bulunan duyusal sinirlerin anormal stimulasyonu sonucu ortaya çıkmaktadır ve lokal olabileceği gibi yansıyan ağrı paterni de gösterebilmektedir. ${ }^{16}$

\section{Tendon ve Ligament Relaksasyonu - Etiyoloji}

Travma: Ligament yaralanmasının en sık nedeni travmalardır. Travma esnasında kollajen liflerinde oluşan yırtılmalar ligament relaksasyonuna neden olmaktadır. Ligament yaralanmaları eklemlerde basit burkulma şeklindeki hafif travmalara bağlı oluşabileceği gibi daha ileri düzeydeki travmalara bağlı da oluşabilir. Genellikle araç içi kazalar sırasında gözlemlenen makaslama yaralanması ve servikal whiplash yaralanma ileri düzeydeki travmalara örnek olarak verilebilir.

Tendon ve ligament yaralanmaları toplumda sık gözlenen bir durumdur. ABD de bildirilen yıllık 33 milyon kas iskelet sistemi yaralanması vakasının yaklaşık \%50'si tendon ve ligament yaralanması içermektedir. ${ }^{17}$ Genel popülasyondan her yıl daha fazla kişinin fiziksel aktivitelere ve fi- 
ziksel performans içeren eğlence faaliyetlerine katılımının giderek artmasıyla, ligament ve tendon yaralanmalarının sıkılığı da artmaktadır.

Mevcut bir ligament relaksasyonu üzerine eklenen ve normalde hafif düzeyde disabiliteye neden olabilecek tekrarlayan bir ligament yaralanması, ileri düzeyde bir disabiliteyle sonuçlanabilmektedir. Tekrarlayan ligament yaralanmaları ciddi eklem disabilitesine neden olmaktadır. ${ }^{2}$

Eklem Dejenerasyonu: Ligament relaksasyonu, travma öyküsü olmadan da gelişebilmektedir. Yaşla birlikte ortaya çıkan eklem dejenerasyonu ligamentler üzerinde fazladan yük oluşturmakta ve hasarlanmaya neden olmaktadır. Örnek olarak lomber bölgede intervertebral disklerde, vertebra korpuslarında ve faset eklemlerde oluşan dejenerasyon (ve eklem aralıklarındaki daralma) posterior ligamentler üzerinde fazla yüklenmeye neden olmakta ve laksiteye zemin hazırlamaktadır.

Hormonal Etkiler: Hormonal etkiler de ligament laksitesi üzerinde etkili olan faktörlerdendir. Kadınlarda seks hormonları, ligament yaralanmasi ${ }^{18,19}$ ve kollojen metabolizmass ${ }^{20}$ üzerinde etkili görülmektedir ve bu hormon düzeylerinin menstrüel siklus boyunca dalgalanıyor olması kadınlarda ligament yaralanması için risk oluşturmaktadir. $^{21}$

Gebelik: Gebelik döneminde, östrojen ve progesteron düzeylerinin giderek arttığı 6. hafta ile 42. hafta arasında eklem laksitesinde de progresif olarak belirgin bir artış olmaktadır. Gebelikte periferik eklemlerdeki laksite, gebelik süreci ilerledikçe giderek artmakta ve 3 . trimestırda ligament laksitesi en belirgin düzeye erişmektedir. Ligament relaksasyonu gebelik döneminde ve postpartum dönemde gelişen bel ve eklem ağrılarının önemli bir nedenidir.

Kırıklar: Eklem bölgesine yakın kemik fraktürlerine sıklıkla ligament yırtıkları da eşlik etmektedir ancak bu vakalarda genellikle sadece fraktürlere odaklanıldığı için kırık iyileşmesi sonrası kalıcı eklem laksitesine yol açabilecek olan ligament yırtıkları gözardı edilmektedir. Bunun sonucunda da uzun süreli istirahati takiben kırık iyileşmesine rağmen, ilerleyen dönemlerde hastada kronik eklem disabilitesi ve günlük yaşam aktivitelerinde kısıtlanma gelişebilmektedir.

Operasyonlar: Ameliyatlar sırasında hastaya verilen bazı pozisyonlar da ligament relaksasyonuna neden olabilmektedir. Hastaların anestezi altında oldukları dönemde özellikle de jinekolojik operasyonlar sırasında lomber bölgede ligament hasarı gelişebilmektedir. Bu durum hastanın operasyon sırasında anestezi altında uzun süre trendelenburg veya jack-knife pozisyonuna kalmasına bağlıdır.

Genetik Yatkınlık: Tendon ve ligament yaralanmalarının etiyolojisinde yer alan birçok iç ve dış faktör gösterilmiş olmakla birlikte genetik faktörlerin etkileri de değerlendirilmektedir. Aşil tendon yaralanmasının genetikle ilişkisi araştırılmış ve genetik predispozisyon olduğunu destekleyen bulgular saptanmıştır. ${ }^{22}$ Spefisik bir genle ilişkilendirilmiş olmasalar da rotator kuf yaralanmalarında ${ }^{23}$ ve ön çapraz bağ yaralanmalarında da ${ }^{24}$ genetik faktörlerin rol oynadıkları gösterilmiştir.

Konjenital Ligament Laksitesi: Ligament laksitesi ve dolayısıyla eklem instabilitesi çeşitli konjenital hastalıklarda da görülebilmektedir. Bu hastalıklardan en sık görüleni Benign Eklem Hipermobilite Sendromu, otomozal dominant geçişli genetik bir hastalıktır ve etiyopatogenezinde kollajen anomalisi rol oynamaktadır. ${ }^{25}$ Çoklu eklem hipermobilitesi hastalığın karakteristik özelliğidir.

Eklem hipermobilitesi Marfan sendromu, Ehlers Danlos sendromu, Down sendromu, Stickler Sendromu gibi başka konjenital hastalıklarda da gözlenen bir bulgudur.

\section{Tendon ve Ligament Relaksasyonu - Semptomlar}

Ligament ve tendon relaksasyonun ana semptomu ağrıdır. Ağrı hareketle artar, istirahatle azalır. Bunun nedeni aktivite sırasında tendon ve ligamentlerin üzerlerine binen 
yüke bağlı olarak gerilmeleridir. Hastalar bu ağrıyı 'keskin bir ağrı' veya 'acı hissi' olarak tanımlayabilir. Şiddetli vakalarda özellikle de hareket esnasında 'bıçak saplanır' tarzda bir ağrı olarak da tanımlanabilir. Birçok hastada günlük yaşam aktivitelerinde kısıtlanma gözlenebilir. Ligament eklemi stabilize edemediğinde, eklem çevresindeki kaslar eklemde stabilizasyonu sağlamak için aşırı kasılırlar. Tekrarlayan eklem aktiviteleri sonucunda kasların etkilenen bölgeyi stabilize etme çabasına bağlı olarak sıklıkla çevre kaslarda spazm gelişir. Kas spazmının olaya katılmasıyla hem ağrı şiddetinde artış olur hem de hasta ağrıyı daha geniş bir alanda hissetmeye başlar. Bu durum tanıda karışıklığa yol açabilmektedir. Hasta istirahat ettiğinde ve analjezik kullandığında kas ağrısı ve spazmında azalma oluşması ligament relaksasyonun tanısını düşündürmelidir.

Kronik kas spazmı olan hastalarda altta yatabilecek ligament laksitesi mutlaka düşünülmelidir, bir eklemde eğer ligament yetersiz kalıyorsa buna sekonder kas spazmı gelişecektir. Bu durum fizik tedavi modaliteleri, masaj gibi uygulamaların ve analjezik, myorelaksan ilaçların kullanımının birçok vakada ağrıyı belirli bir düzeye kadar düşürmesine rağmen sorunun devam etmesinin nedenini açıklamaktadır. Çünkü kas spazmı çözülüp ağrı azalmış olsa da altta yatan esas neden yani ligament laksitesi ve eklemde instabilite devam etmektedir.

\section{Ligamanet Relaksasyonunda Ağrı, Tetik Noktalar ve Yansıyan Ağrı Paternleri}

Ligament relaksasyona bağlı ağrıyla ilgili en karakteristik özelliklerden birisi ağrının yayılım göstermesi yani yansıyan ağrıya neden olmasıdır. Ligament relaksasyonuyla ilişkili yansıyan ağrı, etkilenen bölgeye göre spesifik yayılım paternleri göstermekte ve duyarlı nokta palpasyonuyla birlikte değerlendirildiğinde tanısal açıdan çok değerli bir katkı sağlamaktadır.

Lomber bölgenin ligamentlerinin relaksasyonu ile ilişkili yansıyan ağrı paternleri, George S. Hackett tarafından 19 yıl boyunca, 1656 hastada uyguladığ 18000 intraligament enjeksiyonu sonrasında tanımlanmıştır. ${ }^{2}$ Hackett, sıklıkla sakroiliak ligament yaralanmalarının bacağa yayılan ve ayağa kadar inen yayılım ağrısına neden olduğunu ve bu nedenle de siyatalji olarak tanımlandığını belirlemiştir. Benzer şekilde kalça eklem ligamentleri yaralanmalarına bağlı ağrı da bacağa yayılmakta ve ayak başparmağına kadar inebilmektedir (şekil 1).

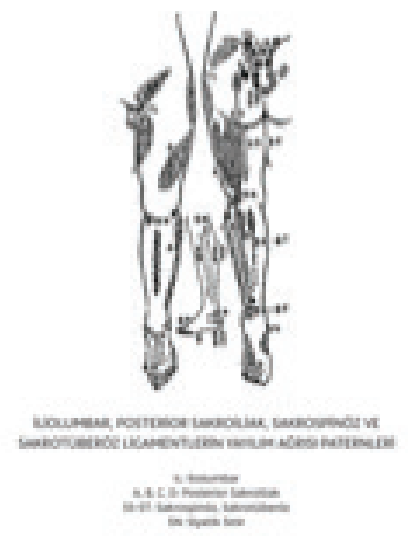

Şekil 1: lomber bölge ve kalça ligament yaralanmalarında yansıyan ağrı paternleri (Hackett, G.S. Ligament and Tendon Relaxation Treated by Prolotherapy)

Ligament ve tendonların yapısında duyusal sinir liflerini içeren fibröz bantlar bulunmaktadır. Bu fibröz bantlar relaksasyonun en sık gerçekleştiği ve sinir dokusunun en fazla olduğu yer olan fibro-ossöz yapışma bölgelerinde daha yoğun olarak bulunmaktadır. Ligament ve tendonlardaki bu duyusal sinirlerin asıl görevi propriosepsionla ilgili uyarıları santral sinir sistemine iletmektir. Bu somatik propsioseptif aferent duyusal uyarılar esas olarak ligamentlerden gelir ve eklemlerin tüm pozisyonlardaki stabilitesine katkıda bulunur.

Ligamentlerden gelen afferent uyarılar spinal dorsal kök ganglionuna girerler. Normal şartlarda bu uyarılar sıklıkla bilinç düzeyinde algılanmazlar ve esasen omurilik düzeyinde refleks aktivitelerle veya serebellum düzeyinde postur ve hareket kontrolü ile ilgilidirler. Normal bir ligament aşırı yüklenmeye maruz kaldığında veya laksite gelişmiş ligamente normal sınırlarda bir yüklenme olduğunda ise 
duyusal iletiler bilinç düzeyinde algılanarak uygulanan yükün istemli olarak azaltılması sağlanır. Ligamentte herhangi bir nedenle laksite geliştiğinde normal sınırlardaki yüklenmelerde dahi ligamentin fibröz liflerinde gerilme ve normalin dışında uzama oluşur. Bu durum intraligamentöz duyusal sinir lifleri üzerinde devam eden anormal gerilim stimulasyonuna neden olur. Ligament relaksasyonuna bağlı olarak eklem mekaniğinin bozulması sonucunda ekleme binen yüklerin oluşturduğu anormal gerilim ligamentten spinal dorsal kök ganglionuna iletilen yoğun uyarılara neden olur ve bu uyarıların bir kısmı santral sinir sisteminde lokal ağrı olarak algılanır. Ligament relaksasyonunda lokal ağrı ve duyarlı-tetik noktalar bu şekilde oluşmaktadır.

Serbest sinir uçlarında duyusal uyarıya neden olan şey "gerilimdir". Lokal anestezi ile opere edilen hastalarda gözlenen ve karın içi organların pediküllerindeki gerilmeye bağlı olarak ortaya çıkan lokal ve yansıyan ağrının nedeni de budur. Somatik ağrı, fiziksel nedenlere bağlı ortaya çıkan ve afferent sinirlerle taşınan rahatsız edici duyunun bilinç düzeyinde algılanmasıdır. Ani olarak başlar, keskindir, iyi lokalize edilir, batma, sızlama veya zonklama tarzındadır, belirgin ve iyi tanımlanan yayılım paterni gösterebilir. Ligament relaksasyonuna bağlı ağrı farklı hastalarca farklı şekilde tanımlanabilir, ayrıca ağrının şiddeti de hastalarda değişkenlik gösterir. Hastalar ligament relaksasyonuna bağlı ağrıyı anlatırken sıklıkla; keskin, bıçak saplanır gibi, acıma şeklinde, yanma, uyuşma, basınç, baskı, çekme, s1kışma, delici ağrı gibi ifadeler kullanırlar. Kısa süreli ve hafif bir stimulasyon sıklıkla sadece lokal bir ağrıya neden olurken, uyarının süresi uzadığında veya şiddeti arttığında genellikle yansıyan ağrı da eşlik etmektedir.

Tetik Nokta Ağrısı: Basınç ve gerilime karşı normalden hızlı ve artmış şiddette bir yanıt oluşumuna neden olan hipersensitif somatik duyusal sinir reseptörlerinin yoğun bulunduğu bölgelere tetik nokta denilmektedir. Etkilenen tendon ve ligamentler ne kadar fazlaysa bu bölgenin sınırları da o kadar geniş bir alanı kapsamaktadır. Tetik nok- talar; ağrıya neden olan tendon veya ligamentin tespitini, iğneleme yöntemiyle tanının doğrulanmasını ve proloterapi enjeksiyonlarında iğnenin doğru bir şekilde yönlendirilmesini sağladığı için tanı ve tedavide çok önemli yapilardir.

Lumbosakral ve pelvik bölge ligamentlerinin relaksasyonuna bağlı oluşan tetik noktalar ve lokalizasyonu doğrulamak için uygulanan iğneleme yönteminde iğne uçlarının yönleri George S Hackett tarafından tanımlanmıştır. ${ }^{2}$ (Şekil 2)

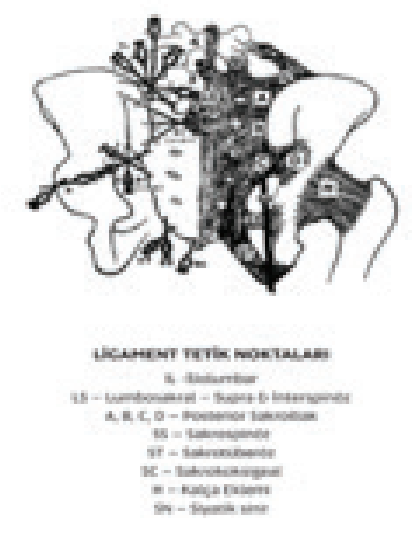

Şekil 2: Lumbosakral-pelvik bölge ligament yaralanmalarında oluşan tetik noktalar ve lokalizasyonu doğrulamak için uygulanan iğneleme yönteminde iğne uçlarının yönleri (Hackett, G.S. Ligament and Tendon Relaxation Treated by Prolotherapy

Yansıyan Ağrı: yansıyan ağrı her türlü ağrılı durumda ortaya çıkabilen ve toplumda ağrılı bireylerde sık rastlanan bir olgudur 26 Uluslararası Ağrı Araştırmaları Derneği (IASP) tarafından 'kaynaklandığg yerin dişında farklı bir lokalizasyonda algılanan ağrı” olarak tanımlanmıştır. ${ }^{27}$

Yansıyan ağrı, birçok dermal ve viseral afferent lifin, ağrı yolu üzerinde aynı ikinci nöron üzerine konverjansı ile açıklanmaktadır. Ligament laksitesi geliştiğinde normal sınırlardaki gerilim kuvvetleri dahi ligamentten spinal dorsal kök ganglionuna iletilen yoğun afferent somatik 
proprioseptif uyarılara neden olur ve bu uyarıların bir kısmı beyne iletilerek lokal ağrı olarak algılanır. Ayrıca primer afferent lifler, nosiseptif somatik afferentlerle birlikte aynı spinal segmente girerek aynı sensoriyel projeksiyon hücrelerini etkileyebilmekte ve bu hücrelerin aktivasyonu sonucu ortaya çıkan uyarıların hangi bölgeden gelirse gelsin ağrı olarak algılandığı ve bu şekilde yansıyan ağrının ortaya çıktığg düşünülmektedir. ${ }^{28}$

Ligament laksitesine bağlı ortaya çıkan tüm yayılım ağrılarını yansıyan ağrı olarak düşünmemek gerekir. Örneğin iliolumbar ligament laksitesine eşlik eden lateral femoral kutanöz sinirin direkt etkilenmesi sonucu ortaya çıkan nöralji, uyluk lateraline yayılan ağrıya neden olur. Buradaki mekanizma afferent liflerin omurilikteki ağrı yollarıyla ve aynı spinal segmental inervasyonla ilişkili değildir ve ligament relaksasyonuna bağlı etkilenen sinirde gelişen nöralji sonucu sinirin trasesi boyunca ağrının yayılmasıdır. Benzer şekilde sakrospinöz ve sakrotuberöz ligamentlerin relaksasyonu sonucu pudental sinirin tuzaklanması ile pudental nöralji oluşabilir, nöralji geliştiğinde de genital ve rektal bölgeye yayılan ağrı oluşur.

\section{Entezis}

Proloterapi enjeksiyonlarında, yaralanmanın tespit edildiği tendon veya ligamanın kemiğe yapışma bölgelerine proliferan madde verilmektedir. Enjeksiyonlarının uygulandığı kollajen liflerin, fibrokartilajın, kartilaj ve kemiğin kompleks bağlantı yeri olan bu bölge "entezis" olarak bilinmektedir (şekil 3). Eğer ortopedik cerrahinin hedef organı kemik ise; proloterapinin hedef organı entezistir denilebilir.

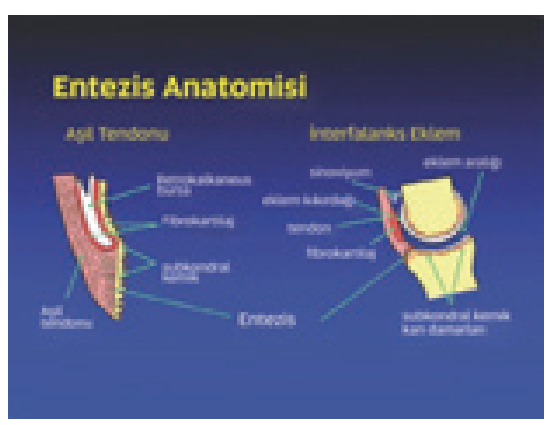

Şekil 3: Entezis anatomisi (McGonagle D, et al. Curr Rheumatol Rep 2002; 4:500-506.)

Ligament ve tendonlar entezis adı verilen bu anatomik bileşkeyi paylaşmaktadırlar. Entezis bölgesinde kollajen fibrilleri yayılarak son derece sağlam bir bileşke oluşturmaktadir.

Entezisin kanlanması göreceli olarak zayıftır. Normal şartlar altında kan desteği intraligamentöz ve intratendinöz damarlar ile kemiğin besleyici damarlarından gelir. Güçlü yapılar tensil kuvvete dayanmayı gerektirirler bu da onların daha yoğun ve avasküler olmasına neden olmaktadır. Avaskülarite fibrokartilajinöz entezisin düzgün, iyi sınırlı ve vasküler foramenden yoksun görünümünü açıklamaktadir. Entezis bir ligamentin innervasyondan en zengin alanıdır. Bu innervasyon myelinli A delta ve myelinsiz C ağrı lifleriyle sağlanır. Bu liflerin bol olması ligament yaralanması oluştuğunda ağrıya neden olarak yarlanmanın aşikâr olmasını sağlamaktadır. (şekil 4)

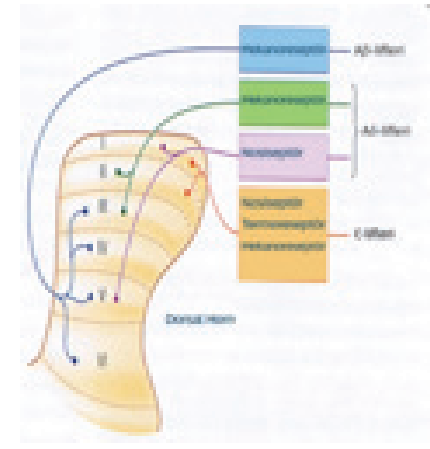

Şekil 4: A delta ve C liflerinin omurilik arka boynuzunda sonlanmaları 
Tendonların ise diğer bölümleri iyi innerve olmasına rağmen entezis bölgelerinde ya çok az innervasyona sahiplerdir ya da bu bölgede innervasyonları yoktur. ${ }^{29}$ Embriyonal dönemde mezoderm, kemik, kas, ligament, tendon, periosteum ve kıkırdak dokularına farklılaşırken, farklılaşmış bu dokular arasında tendon ve ligamentlerin periosteum içinde, kemiğin fibröz matriksiyle birlikte devamlılığını oluşturan inelastik fibröz bir doku oluşmaktadır. Zamanla kemiğin kalsiyum içeriği ligament ve tendonların bu fibro-ossöz bağlantı bölgesindeki dokuyu zayıflatır ve bu da tendon ve ligamentin bu bölgedeki esnekliğini ve gerilime karşı dayanma kuvvetini belirgin derecede azaltır. Sonuç olarak entezis bölgesi yaralanma için en yatkın bölge haline gelir.

Eklemde yüksek gerilim kuvveti oluştuğunda ligamentlerin özellikle fibro-ossöz bağlantı noktasında yaralanmalar1 sonucunda ligament laksitesi oluşur ve bu da zamanla eklemde instabilite gelişmesiyle sonuçlanır. Ligamentlerin entezis bölgesindeki zengin inervasyonu nedeniyle ve ligament laksitesinin çevre kas dokusundaki kontraksiyonlarla kompanse edilmesine bağlı gelişen kas spazmı sonucunda ağrılı bir süreç gelişir. Aynı zamanda eklemin antagonistik kaslarının inhibisyonuna neden olan bu süreçte kas atrofisi de ortaya çıkmakta ve bu da eklem instabilitesine katkıda bulunmaktadır. Sonuç olarak eklem yaralanmaları sonucu ortaya çıkan ağrının büyük oranda ligament ve özellikle de entezis kaynaklı olduğu söylenebilir.

Akut ligament ve tendon hasarları ideal koşullar altında enflamasyonla iyileşen tendon ve ligamentin orjinaline restore olan bir doku destrüksiyonu ile sonuçlanmaktadır. Proloterapi, akut lokalize doku hasarı bölgesinde doğal inflamasyona neden olarak onarım sürecini başlatır. Entesisteki akut hasarlanma doğal olarak ya da proloterapi yardımıyla iyileşebilirken, kronik hasarlanma rezidüel efektif akut inflamatuar iyileşme cevabından yoksundur. Kronik hasarlanma sürecinde entezis dokusunda lenfosit infiltrasyonu baskındır ve doğal olarak etkili bir iyileşme gerçekleşmemektedir. Proloterapi enjeksiyonları ile akut yaralanmada olduğu gibi kronik yaralanmalarda da tendon ve ligamentlerde enflamasyon yanıtının oluşması ve yara iyileşme sürecinin başlatılması hedeflenmektedir.

Bir insersiyo bölgesinde dağılan yüklenmelerde, entesis fibrokartilajının koruyucu etkinliğine rağmen tekrarlayan hasarlanmalar olması sonucu entezis bölgesinde tamamlanmamış iyileşmeyle sonuçlanan doku mikrotravmaları oluşabilmektedir. Mikrotravmatik hasarlanmalar, tekrarlayan hafif şiddetli yüklenmelerle o bölgenin zayıf kanlanmasının kombinasyonu sonucu ortaya çıkmaktadır. Bu durum, iyileşmeyen kronik hasarlanmaların neden insersio alanında daha sık olduğunu açıklamaktadır.

Normal şartlarda dokuların yara iyileşmesi sürecinde gözlemlenen sıralı yara iyileşme kaskadı, kronik mikrotravma alanlarında ya yoktur ya da başarısız bir şekilde sonuçlanmıştır. Bu mikroskopik seviyedeki travmalar, ligament ve tendonlardaki fibroblastların ve kollajenöz matriks komponentlerinin hipoksik hasarının sonucudur. ${ }^{30}$

Eklemlerde ligament yaralanmalarının sıklıkla entezis bölgesinde oluşması, fibro-ossöz bölgedeki iyileşme sürecinin tam olarak gerçekleşmemesi sonucu ligament relaksasyonu ve dolayısı ile eklem instabilitesinin gelişmesi, proloterapi enjeksiyonlarında proliferan solüsyonun entezis bölgelerine ve kemik teması alarak uygulanmasının neden çok daha iyi sonuçlar verdiğini açıklamaktadır. Direkt ligament enjeksiyonları ile ligament rüptürü oluşma riski yüksek olmakla birlikte klinik sonuçları da entezis enjeksiyonları kadar iyi değildir.

\section{Proloterapi Etki Mekanizması}

Proloterapi enjeksiyonlarının etki mekanizmasının anlaşlabilmesi için dokularda yara iyileşmesi sürecini iyi anlamak gerekmektedir. Çünkü proloterapi'nin etki mekanizmasının temelinde milyonlarca yıldır devam eden bu doğal yara iyileşmesi süreci yatmaktadır. Yara iyileşmesi ve doku onarımı süreci tüm büyük memelilerde aynıdır ve 60 milyon yıldan fazladır değişmeden kalmıştır. Son yüzyıl- 
da yapılan araştırmalarla doku onarım süreci ayrıntılarıyla incelenmiş ve bu rejeneratif sürecin sırları ortaya konulmuştur.

Yara iyileşmesi; hasarlanan dokunun yapısal bütünlüğünü ve fonksiyonel kapasitesini geri kazanmaya yönelik olarak işleyen karmaşık ancak kendi içinde bütünlüğü olan, hücresel ve moleküler olaylar dizisi sonucu gerçekleşmektedir. $\mathrm{Bu}$ süreç, birbiri ardına gelişen ancak aynı zamanda iç içe geçmiş 3 temel evrede gerçekleşmektedir (şekil 5).

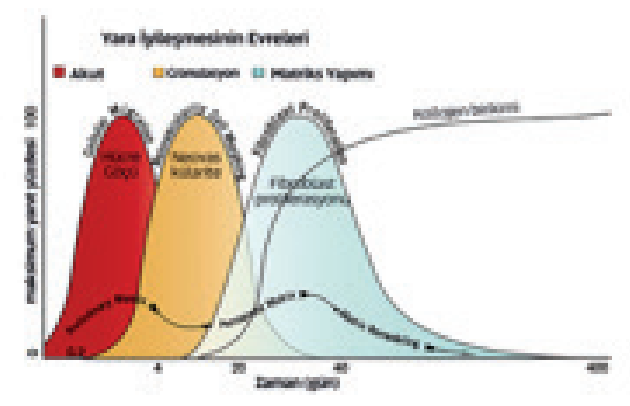

Şekil 5: yara iyileşmesinin evreleri

\section{Yara İyileşmesinin Evreleri}

1 - Hemostaz ve enflamasyon evresi : Bu evrede öncelikle lokal damar cevabı olarak tromboksan A2 gibi araşidonik asit metabolitlerine bağlı vazokonstrüksiyon gelişir ve kısa süreli geçici hemostaz sağlanır. Bunu koagulasyon ve trombosit agregasyonu izler ve damar lümeninde fibrin tıkaç oluşur. Pıhtı ve yara çevresindeki dokulardan proinflamatuvar sitokinler ve büyüme faktörleri salınmasını takiben enflamatuvar hücreler yara dokusuna doğru hareket ederler. Enflamasyon sırasında, yarada hücreden zengin bir ortam gelişir. Bu evre, 3 - 5 gün içinde sona ermektedir. Enflamasyon; organizmayı kan kaybına karşı korumak, yabancı madde invazyonunu önlemek ve yara dokusunu onarıma hazır hale getirmek için gelişen bir reaksiyondur. ${ }^{31}$

2. Proliferasyon evresi: Yaralanma sonrası 3. günde başlayan bu evre 3 hafta kadar devam etmektedir. Enflamatuvar evre döneminde salınan sitokinler ve büyüme faktörleri proliferasyon fazının da başarılı bir şekilde tamamlan- masını sağlamaktadır. Bu fazda yaralanmış dokunun güçlendirilmesi gerçekleşmektedir. ${ }^{32} \mathrm{Bu}$ dönemde yara bölgesindeki enflamatuar hücrelerden salınan sitokinlere ve büyüme faktörlerine yanıt olarak fibroblastlar yeni hücre dışı matriks ve olgunlaşmamış Tip III kollajen sentezlemeye başlarlar. Ayrıca bir dizi büyüme faktörü salgılayan uyarılmış fibroblastlar bir 'geri bildirim (feedback) döngüsü " oluşturarak iyileşme sürecini desteklemektedir. Kollajen birikimi yaranın gerilmeye karşı direncini hızla arttırır.

3. Remodelizasyon (yeniden yapılanma) evresi: Yara bölgesindeki fibroblast sayısının azaldığı, kollajen üretiminin dengeye ulaştığı, hücre proliferasyonunun tamamlandığg, yara gerilim direncinin arttığ 1 , skar dokusunun hacminin azaldığı ve sonuçta iyileşmiş skar dokusunun oluştuğu evredir. Sitokin ve büyüme faktörlerinin etkisiyle kollajen matriks devamlı yıkılmakta, yeniden sentezlenmekte, organize olmakta ve çapraz bağlarla skar içinde stabilizasyonu sağlanmaktadır. Fibroblastlar ortadan kaybolmaya başlarken ve proliferasyon fazında depolanan Tip III kollajen yerini daha güçlü olan Tip I kollajene bırakmaktadır. Skar dokusundaki kollajen liflerin yeniden düzenlenmesi ve artan çapraz bağlarla iyi organize olmaları sonucunda skar dokusunun gerilim gücü zamanla artarak orjinal dokunun gerilim gücünün en fazla \%80'ine ulaşır. ${ }^{32}$ Yeniden yapılanma evresi birkaç yıl sürebilmekte ve matriksteki yıkım ve yapım arasında ince bir dengeyi gerektirmektedir.

Proloterapi enjeksiyonları sonrasında, proliferan solüsyonun uygulandığ da veya etkinliğinde artış olmaktadır.

Büyüme faktörleri yara iyileşmesinde doku tamirinde ve hücre proliferasyonunda ana rolü oynayan polipeptid formunda kompleks proteinlerdir. Yara iyileşmesi sürecinde büyüme faktörleri anjiogenez, hücre proliferasyonu, ekstrasellüler matriks formasyonu, hücre farklılaşması gibi olaylarda çok önemli rol oynamaktadır (tablo 1) 


\begin{tabular}{|c|c|}
\hline $\begin{array}{l}\text { Platalet Kaynaklı Büyüme Faktörü } \\
\text { (PDGF) }\end{array}$ & $\begin{array}{l}\text { - Hücre bölünmesini uyarır } \\
\text { - Anjiogenezi uyarır } \\
\text { - Epitelizasyonu uyarır } \\
\text { - Doku oluşumunu uyarır }\end{array}$ \\
\hline $\begin{array}{l}\text { Transforming Büyüme Faktörü } \\
\text { (TGF) }\end{array}$ & $\begin{array}{l}\text { - Ekstraselülar matriks oluşumunu } \\
\text { uyarır } \\
\text { • Kemik hücre metabolizmasını } \\
\text { düzenler }\end{array}$ \\
\hline $\begin{array}{l}\text { Damar endoteli büyüme faktörü } \\
\text { (VEGF) }\end{array}$ & - Anjiogenezi uyarır \\
\hline Epidermal büyüme Faktörü (EGF) & $\begin{array}{l}\text { - Hücre farklılaşmasını \& re-epiteli- } \\
\text { zasyonu, anjiogenezi \& kollojenaz } \\
\text { aktivitesini uyarır }\end{array}$ \\
\hline Fibroblast büyüme faktörü (FGF) & $\begin{array}{l}\text { - Endotel hücrelerin ve fibroblast- } \\
\text { ların proliferasyonunu uyarır } \\
\text { - Anjiogenezi uyarır }\end{array}$ \\
\hline
\end{tabular}

Platalet Kaynaklı Büyüme Faktörü (PDGF)

- Hücre bölünmesini uyarır

- Anjiogenezi uyarır

- Epitelizasyonu uyarır

- Doku oluşumunu uyarır

Transforming Büyüme Faktörü (TGF)

- Ekstraselülar matriks oluşumunu uyarır

- Kemik hücre metabolizmasını düzenler

Damar endoteli büyüme faktörü (VEGF)

- Anjiogenezi uyarır

- Epidermal büyüme Faktörü (EGF)

- Hücre farklılaşmasını \& re-epitelizasyonu, anjiogenezi \& kollojenaz aktivitesini uyarır

- $\quad$ Fibroblast büyüme faktörü (FGF)

- Endotel hücrelerin ve fibroblastların proliferasyonunu uyarır

- Anjiogenezi uyarır

İn vitro koşullarda transforming büyüme faktörü-Beta (TGF-Beta), insülin benzeri büyüme faktörü-1 (IGF-1), temel fibroblast büyüme faktörü (bFGF) içeren bir karış1ma maruz kalan insan kıkırdak hücrelerinde proliferasyon gerçekleşmektedir. ${ }^{33,34}$

İn vivo hayvan deneylerinde diz eklemine TGF-Beta veya
bFGF enjeksiyonu sonrası eklem kıkırdağında kondrogenesiz oluştuğu gösterilmiștir. ${ }^{35}$ Ayrıca tam kat kıkırdak defektlerinin hepatosit büyüme faktörü (HGF) enjeksiyonu sonrasında tamirinin gerçekleștiği de bildirilmiştir. ${ }^{36}$

İnsan kıkırdak hücreleri birçok büyüme faktörünü oluşturma potansiyeline sahip olduğu için ve ayrıca tendon, ligament yaralanması sonrası tamir sürecinde bölgedeki hücreler büyüme faktörleri salgılandığ 1 için eğer bu faktörlerin salgılanması stimule edilirse benzer şekilde iyileşme süreci de başlatılmış olacaktır. Proloterapi enjeksiyonlarının etki mekanizmasındaki temel mantık da budur. Büyüme faktörlerinin modülasyonu üzerinden etkinliği nedeniyle proloterapi için Rejenerasyon Enjeksiyon Tekniği (RET) tanımı da kullanılmaktadır.

Proloterapi enjeksiyonlarında, proliferan solüsyonun uygulandığı bölgede lokal enflamasyon oluşmakta ve bu da büyüme faktörlerinin salınımını ve kollajen depozisyonunu tetiklemektedir. Yani proloterapi enjeksiyonları; doku iyileşmesinin üç aşaması olan enflamasyon, proliferasyon ve remodelizasyon evrelerini uyararak doğal doku iyileşmesi sürecini taklit etmektedir (şekil 6).

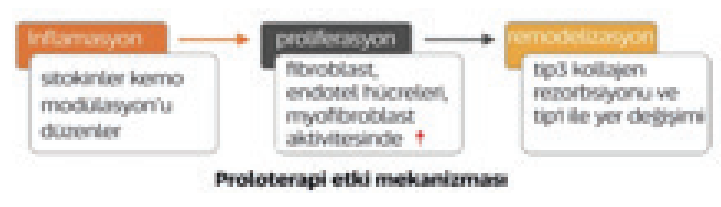

Şekil 6: proloterapi etki mekanizması

Proloterapi; büyüme faktörleri uyarıcılarının veya büyüme faktörlerinin enjeksiyonu veya hücre ve dokularda büyüme ve proliferasyona neden olan maddelerin enjeksiyonu olarak tanımlanabilir.

\section{Proloterapi Enjeksiyonlarında Kullanılan Maddeler}

Proloterapi yönteminde, yaralanmış tendon ve ligamentlerde veya kıkırdak dokuda lokal enflamasyonun tetiklenmesi ve büyüme faktörlerinin salınımı yoluyla veya hasarlı 
dokuda doğrudan hücre proliferasyonunun tetiklenmesiyle doku onarımının gerçekleşmesi hedeflenir. Bu amaçla farklı maddeler kullanılmaktadır;

Tahriş Ediciler (fenol, guaiacol): Reaktif quinine bileşiklerine okside olan 'fenol hidroksil' grubu içermektedirler ve direkt oksidasyona yol açarak enflamatuvar kaskadı tetiklemekte ve böylece hücre harabiyetine neden olmaktadırlar. Fenol enjeksiyonuna bağlı alerjik reaksiyon sonucu iki ölüm vakası bildirildikten sonra bu bileşikler günümüzde çok fazla kullanılmamaktadır.

Partikülatlar (ponza unu): Bakterilerle benzer şekilde uygulama alanına makrofaj hüclerini çekerek etki ederler. Önce enjeksiyon alanına makrofajlar gelir ve bu granülleri fagosite eder. $\mathrm{Bu}$, makrofajların polipeptid büyüme faktörlerini salmasına neden olur ki bu da fibroplazi ve yeni kollajen depozisyonu ile sonuçlanır.

Osmotik Ajanlar (dekstroz, gliserin): Enjeksiyon bölgesinde hücrelerin osmotik dengesini bozmaları sonucu dehidratasyona yol açarak etki ederler.

Kemotaktik Ajanlar (sodyum morrhuate, sylnasol): Sodyum morrhuate balık karaciğgerinden elde edilen bir sodyum tuzudur. Poliansature yağ asitlerinden zengin olan bu ajan prostoglandin, tromboksan ve lekotrienler gibi inflamatuvar mediyatörlerin öncüsü bir bileşiktir.

Trombositten Zengin Plazma (PRP): Otolog kanın santrifüj edilmesi yoluyla trombositten zengin plazma elde edilir, bu plazma hasarlı bölgeye enjekte edilerek trombositlerden salgılanan büyüme faktörlerinin doku onarıcı etkileri ile iyileşme hedeflenir.

Büyüme Faktörleri: Büyüme faktörlerinin tek başına veya proliferan solüsyonla birlikte hasarlı bölgeye enjekte edilmesi de proloterapide kullanılan bir yöntemdir.

Proloterapi enjeksiyonlarında en sık kullanılan solüsyon "dekstrozdur."

Dekstroz, proloterapi enjeksiyonları için ideal bir proliferandır, suda çözünür olması ve kan biyokimyasının normal içeriğinde yer alması nedeniyle oldukça güvenli bir maddedir. Bu nedenle de vücudun birçok bölgesine ve yüksek miktarlarda uygulanabilmektedir. Kolay elde edilebilmesi ve ekonomik olması da yaygınlaşmasında etkili olmuştur. Dekstroz proloterapisi direkt etki, osmotik etki, inflamatuvar büyüme etkisi gibi birçok mekanizma üzerinden etki etmektedir. Proloterapi enjeksiyonlarında kullanılan dekstrozun konsatrasyonu da önemlidir ve etki mekanizması üzerinde belirleyici faktörlerdendir.

\%10'un altındaki konsantrasyonlardaki dekstroz enjeksiyonları, histolojik enflamasyon reaksiyonu oluşturmaksızın hücre ve dokularda proliferasyonu direkt olarak uyarır. $^{37,38} \% 10$ 'un üzerindeki konsantrasyonlardaki dekstroz enjeksiyonları ise enjeksiyon bölgesinde yoğun bir konsantrasyon oluşturduğu için o bölgedeki hücrelerde osmotik etkiye neden olur. Enjeksiyon bölgesindeki hücreler su kaybederek hasarlanırlar. Bunu enflamatuvar hücrelerin bölgeye gelerek yara iyileşmesi sürecini başlatmaları takip eder.

Normal insan hücresi sadece $\% 0.1$ oranında dekstroz içermektedir. ${ }^{39}$ Glukoz konsantrasyonunun (dekstroz) yükselmesi hücrede protein sentezini, DNA sentezini, hücre büyümesini arttırmakta ve hücre proliferasyonuna neden olmaktadir. ${ }^{40-42}$

Clarkson ve ark. ${ }^{43}$, yumuşak dokuya (bağ dokusu, tendon, ligament) uygulanan dekstroz enjeksiyonu ile büyüme faktörü genlerinin indüksiyonunun ve bunun sonucunda da doku proliferasyonunun gerçekleşebileceğini göstermişlerdir. Lam ve ark. ${ }^{44}$ renal fibroblast hücrelerinde D-glukoz (dekstroz) maruziyeti ile kollajen gen ekspresyonunun indüklenebileceğini göstermişlerdir. Bu çalışmada $5.5 \mathrm{mM}$ ve $25 \mathrm{mM}$ D-glukoz uygulamaları sonrası renal fibroblastlarda bağ doku büyüme faktörü ve insülin benzeri büyüme faktörü-1 ekspresyonunun arttığı gösterilmiştir. 
Yüksek glukozlu ortamda kollajen-I ve kollajen-III'ün alfa alt ünitelerinin (COL1A1, COL3A1) mRNA düzeylerinde artış gözlenmiştir. Glukozla indüklenen kollajen alt ünitesi mRNA ekspresyonunun bağ doku büyüme faktörüne karşı monoklonal antikorla kısmen inhibe olduğu gözlenmiştir. Çalışmada glukozun hiperozmolaritesine bağlı etkisini test etmek amacıyla 25 mM L-glukoz da uygulanmış ancak kollajen ekspresyonunun artmadığı gözlenmiştir. Bu çalışma da dekstroz maruziyeti sonrası büyüme faktörü stimülasyonu tezini desteklemiştir.

Ekstraselüler d-glukoz (dekstroz) konsantrasyonlarındaki çok düşük miktarlarda (\%0.5) bir artış olduğunda dahi, buna maruz kalan normal insan hücreleri prolifere olmaya başlarlar ve trombosit kaynaklı büyüme faktörü (PDGF ${ }^{45}$, epidermal büyüme faktörü ${ }^{46}$ transforming büyüme faktörü-beta (TGF-beta) ${ }^{47,48}$, temel fibroblast büyüme faktörü ${ }^{49}$, insülin benzeri büyüme faktörü (IGF) ${ }^{50}$ ve bağ dokusu büyüme faktörü ${ }^{51}$ gibi birçok büyüme faktörünün salınımı gerçekleşir. Büyüme faktörlerinin etkisiyle hasarlanmış olan ligament ve tendonlarda tamir ve iyileşme gerçekleşir. ${ }^{52,53}$

İnsanlarda ve hayvanlarda yapılan çalışmalarda dekstroz enjeksiyonlarının dokularda enflamasyonu uyardığı, ligament çapını arttırdığı, tendon hipertorfisi sağladığı, fibroblast proliferasyonuna neden olduğu ve eklem k1kırdak defektlerini onardığı gösterilmiştir. ${ }^{54,55}$ Dekstroz proloterapisi, doku onarımı üzerinde sadece enflamasyonun tetiklenmesi ve büyüme faktörleri üzerinden değil başka mekanizmalar üzerinden de etkilidir. İnterlökinler ve plazminojen aktivatörü doku onarımını önemli ölçüde olumsuz etkilemektedirler. Dekstroz maruziyeti sonrasında insan hücrelerinde interlökin 2, 6, 10 ve plazminojen aktivatörünün aktivasyonlarında azalma olmaktadır. ${ }^{56}$

\section{Proloterapi Uygulamaları}

\section{Diz Ağrısı ve Proloterapi Enjeksiyonları}

Diz ekleminde yüksek şiddetli anlık yaralanmalara veya düşük şiddetli tekrarlayan yaralanmalara bağlı oluşan tendon ve ligament hasarlanmaları ve bunun sonucunda oluşan laksite-instabilite diz ağrısının en sık ve en önemli nedenidir. Diz ekleminin instabilitesine bağlı olarak da k1kırdak dejenerasyonu, menisküs yırtıkları, yeni ligament ve tendon yaralanmaları gibi birçok patoloji gelişebilmektedir.

Proloterapi enjeksiyonları ile birçok diz eklem patolojisinin gelişiminden sorumlu olan tendon-ligament laksitesini vücudun kendi iyileşme mekanizmasını uyararak gidermek ve böylece eklem instabilitesine bağlı oluşan birçok hastalığın gelişimini önlemek veya tedavisini sağlamak hedeflenmektedir.

Ligament yaralanmasına bağlı diz ağrısı olan hastalara uygulanan eklem içi ve eklem dişı dekstroz proloterapi enjeksiyonları ile VAS ağrı skorlarında başlangıca göre \%82 gibi yüksek oranda azalma olduğu bildirilmiştir. ${ }^{57}$

Hauser $\mathrm{A}^{58}$, farklı tedavilere rağmen devam eden kronik diz ağrısı yakınması olan 80 hastada proloterapi enjeksiyonları sonrası hastaların \%96'sında ağrı düzeyi ve tutuklukta anlamlı azalma ve eklem hareket açıklığında anlamlı artış olduğunu, \%82'sinde yürüyüş, anksiyete, depresyon, ağrı kesici gereksinimi skorlarında anlamlı düzelme olduğunu bildirmiştir.

Ligament yaralanmaları dejeneratif artrite neden olabilmektedir. Yeterli tedavi edilmeyen ve iyileşmeyen ligament yaralanmaları ligament relaksasyonu ve zayıflı̆̆ ile sonuçlanır. Ligamentte gerçekleşen relaksasyon eklem instabilitesine ve osteoartritle sonuçlanacak olan eklem biyomekaniğinde bozulma sürecinin başlamasına neden olmaktadır. Literatürde bunu destekleyen birçok veri bulunmaktadır. Örneğin; diz ekleminde ligament yaralanması gelişen kadın futbolcularda 12 yıl içinde diz osteoartriti gelişim riskinin belirgin olarak arttığ 1 gösterilmiştir ${ }^{59}$. Bir başka çalışmada osteoartritin ligament yaralanma insidansının yüksek olduğu bezbol, futbol, basketbol, güreş, boks, Amerikan futbolu, jimnastik gibi sporlarla uğraşanlarda ve 
dansçılarda yüksek sıklıkla gözlemlendiği bildirilmiştir. ${ }^{60}$ Osteoartrit gelişimini inceleyen bazı çalışmalarda, travma ve mekanik stresin osteoartrit gelişimine yol açtığı gerçeği konusunda artık soru işareti kalmadığını belirtilmektedir. $^{61}$

Proloterapi enjeksiyonları ile tendon ve ligamentlerdeki hasarların vücudun kendi iyileşme mekanizması uyarılarak tedavi edilmesi hedeflenmektedir. Ligament laksitesi düzeldiğinde bozulan eklem biyomekaniğinin de düzeleceği ve bu şekilde osteoartrit gelişiminin önlenmiş veya durdurulmuş olacağ d düşüncesi proloterapinin osteoartrit tedavisinde kullanımının temelini oluşturur. Proloterapinin osteoartrit (OA) üzerindeki etkileri özellikle diz osteoartritini konu alan çalışmalar ile araştırılmıştır.

Diz OA olan 90 hastayla yapılan bir çalışmada, hastalar proloterapi enjeksiyonu, saline enjeksiyonu ve egzersiz gruplarına ayrılmışlar. Proloterapi grubuna 4 hafta arayla 3 seans dekstroz proloterapi enjeksiyonları uygulanmış, 52. hafta değerlendirmesinde proloterapi grubunda WOMAC skorlarında diğer iki gruba göre anlamlı düzelme saptanmıştır. Böylece, proloterapinin diz osteoartriti olan hastalarda ağrı, fonksiyonel durum ve tutukluk skorlarında saline enjeksiyonu ve egzersize göre daha ileri düzeyde iyileşme olduğu gösterilmiştir. ${ }^{62}$

46-65 yaş arası orta-ileri düzeyde diz OA olan 36 hastayla yapılan bir çalışmada 1, 5 ve 9. Haftalar olmak üzere 3 seans dekstroz proloterapisi uygulanan hastaların 52. haftada WOMAC skorlarında anlamlı düzelme olduğu saptanmış ve araştırmacılar, proloterapi enjeksiyonlarının diz OA olan hastalarda etkili ve güvenli bir tedavi yöntemi olduğunu bildirmişlerdir. ${ }^{63}$

OA'de Proloterapi uygulamaları ilgili en fazla sorulan sorulardan birisi proloterapinin kıkırdak üzerinde herhangi bir etkisinin olup olmadığıdır. Bu soruya yanıt aramak için yapılan bir çalışmada yaş ortalaması 71 olan ve ortalama 9 yıllık diz ağrısı yakınması olan 6 diz osteoartritli hasta- ya 4-6 seans dekstroz proloterapisi aylık seanslar halinde uygulanmış ve tedaviden sonra değerlendirilen biyopsi örneklerinde yeni kıkırdak oluştuğu gösterilmiştir. Ayrıca hastaların WOMAC skorlarında da anlamlı iyileşme gözlenmiştir. ${ }^{64}$

Diğer kas iskelet sistemi hastalıklarında uygulanan proloterapi seansları sonrasında olduğu gibi diz OA vakalarında da enjeksiyonların etkilerinin ne kadar süreceği sıklıkla sorulan bir diğer sorudur. Diz OA'da proloterapi enjeksiyonlarının olumlu etkileri uzun dönem devam etmektedir. Literatürde diz OA hastalarında proloterapi enjeksiyonlarını takiben ağrı, tutukluk ve fonksiyonel durum skorlarındaki anlamlı düzelmelerin 2.5 yıllık takiplerde de devam ettiği bildirilmektedir. ${ }^{65}$

Wisconsin üniversite'sinde son dönemde yürütülen bir çalışmada proloterapi uygulanan 22 semptomatik diz OA’lı hastanın enjeksiyonlardan 52 hafta sonra değerlendirilmeleri sonucunda 22 hastanın 18'inde yaşam kalitesinde anlamlı artış olduğu belirlenmiştir. ${ }^{66}$

Son dönemde yürütülen bir başka çalışmada, diz OA tanısı olan 24 hasta (ort yaş:58.3) 3 seans uygulanan intraartikülar proloterapi enjeksiyonları sonrasinda 24. Haftada değerlendirilmiş ve VAS ağrı, WOMAC skorlarında ve eklem hareket açıklığında anlamlı iyileşme saptandığı bildirilmiştir. ${ }^{67}$

Proloterapinin diz OA'de etkinliğini araştıran on farklı çalışmayı inceleyen sistematik bir gözden geçirme çalışmasında, proloterapi uygulanan hastalarda ağrı, fonksiyon ve eklem hareket açıklığı skorlarında kısa ve uzun dönemde anlamlı iyileşmeler olduğu belirlenmiş. Bu çalışmalarda hasta memnuniyetinin de ortalama \%82 gibi oldukça yüksek olduğu saptanmıştır ${ }^{68}$. 258 hastayla ilgili verilerden derlenen bir başka gözden geçirme çalışmasının sonucunda, diz OA'da proloterapinin güvenli ve etkili bir tedavi olduğu bildirilmiştir. ${ }^{69}$ 
Güney Kore'de yürütülen bir çalışmada, 6 ay ve daha uzun süredir semptomatik olan, radyolojik olarak grade II ve üzeri diz OA saptanan 20 hastaya uygulanan intraartikular dekstroz proloterapi enjeksiyonları (ayda bir, 3 seans) sonrasında (son enjeksiyondan 1 ay sonra) yapılan değerlendirmede hastaların VAS ağrı skorlarında anlamlı azalma ve WOMAC OA skorlarında anlamlı düzelme saptandığı bildirilmiştir. ${ }^{70}$

Revees ve Hassanein'in ${ }^{71}$ yürüttükleri randomize, çift kör, plasebo kontrollü bir çalışmada, grade II ve daha ileri OA saptanan $38 \mathrm{diz}$ eklemi dekstroz proloterapisi (iki ayda bir- 6 seans, eklem içi) ve bakteriostatik sıvı enjeksiyonu (plasebo) gruplarına ayrılmıştır. 6. Ay değerlendirmesinde dektroz grubunda ağrı, şişlik ve eklem fleksiyon açıklığında plasebo grubuna göre anlamlı düzelmeler saptanmıştır. 12. Ayda dekstroz grubunda ağrıda \%44, şişlikte \%63 azalma saptanırken radyolojik olarak da bazı değişkenlerde (lateral patellofemoral kıkırdak kalınlığı, distal femur genişliğinde artış) anlamlı gelişmeler saptanmıştır.

Menisküs yırtıkları diz ağrısının önemli bir nedenidir ve menisküs yırtıkları nedeniyle uygulanan cerrahi işlemler tüm diz operasyonlarının yaklaşık 1/6'sını oluşturmaktadir. Bu işlemler; total veya parsiyel menisektomi, menisküs tamiri ve nadiren de olsa menisküs transplantasyonudur. Tüm bu yöntemlerde ağrı, tutukluk, kitlenme gibi semptomların ve instabilite'nin rekürrens oranı oldukça yüksektir. Ayrıca, cerrahi sonrası tekrarlayan yaralanma da sık görülmektedir. Menisküs yırtıklarına en agresif yaklaşım menisektomidir ve menisektomi sonrası diz ağrısı yakınması devam eden hastalar, diz eklemi sorunları nedeniyle hekime başvuran hastalar arasında önemli bir grubu oluşturmaktadirlar.

Menisküs yırtıklarında uygulanan mevcut cerrahi yöntemlerin geç dönemde instabiliteye ve eklem dejenerasyonuna yol açma riskleri, bu tedavilerin menisküs yırtıklarında ilk seçenek olmalarının sorgulanmasına neden olmuştur. Lohmander ve $\operatorname{ark}^{72}$, menisküs patolojilerinde cerrahi prosedürlerin etkinliğini konu alan oldukça kapsamlı bir gözden geçirme çalışması yapmışlar ve bu çalışmanın sonucunda 'ön çapraz bağ ve menisküslerin tamiri veya rekonstrüksiyonunun osteoartrit gelişimine karşı koruyucu etkisine dair kanıt bulunmadığını” belirtmişlerdir. Burada önemli olan nokta, cerrahi tekniklerin diz ekleminin travma sonrasında iyileşmesi için gerekli olan rejeneratif süreci başlatamıyor olmalarıdır. Tedavi edilmeyen veya cerrahi uygulanan vakalarda rejenerasyon sürecini başlatacak bir yaklaşım olmazsa travmayla başlayan süreç devam ederek dejenerasyona yol açmaktadır. Bu dejeneratif süreç ancak iyileşme sürecinin uyarılması (rejenerasyon) ile önlenebilmektedir.

Menisküs yırtıklarında, cerrahi yöntemlerin başarı oranının düşük olması ve başarısız tedavinin gonartroz gelişimine zemin hazırlaması nedeniyle son dönemde "biyolojik menisküs tamiri” sağlayacak yöntemler üzerinde durulmaya başlanmıştır. Bu konuda yapılan araştırmalarda hasarlanmış menisküsün ortamda yeterli büyüme faktörü olmaması nedeniyle iyileşemediğini saptanmıştır. İn vitro çalışmalarda platalet kaynaklı büyüme faktörü (PDGF), transforme büyüme faktörü (TGF) ve diğerlerinin menisküs hücre proliferasyonunu ve kollojen gelişimini uyardı̆̆ 1 gösterilmiştir. ${ }^{73-75}$

Proloterapi enjeksiyonları, büyüme faktörlerinin salınımını sağlayarak hücre proliferasyonu ve kollojen yap1mını uyarır. Proloterapi enjeksiyon tekniğinde, büyüme faktörlerinin salınımını uyaran dekstroz gibi solüsyonlar kullanılmaktadır. Proloterapi enjeksiyonlarında en sık kullanılan solüsyon olan dekstroz, enjekte edildiği ortamda IGF-1, TGF- $\beta$, TFG- $\beta$, bFGF, and PDGF-B gibi birçok büyüme faktörünü arttırmaktadır. ${ }^{61,76-80}$

Diz eklemiyle ilgili yakınmaları olan ve menisküs patolojisinin eşlik ettiği 24 hastada 28 diz eklemiyle yapılan retrospektif bir çalışmada, diz eklemine proloterapi enjeksiyonları uygulanmış (ort 6 seans) ve son enjeksiyondan itibaren 18 ay boyunca hastalar takip edilmiştir. Proloterapi'nin 
ağrı ve tutukluk yakınmalarında anlamlı azalmaya yol açtığı kaydedilmiştir. Ortalama VAS ağrı skoru 7.2'den 1.6’ya gerilerken ortalama VAS tutukluk skorunun 6.0'dan 1.2'ye gerilediği saptanmıştır. Ayrıca, proloterapi enjeksiyonları ile eklem hareket açıklığında ve fonksiyonel durumda belirgin gelişme kaydedilmiştir. ${ }^{81}$

Ön çapraz bağ (ÖÇB) yaralanmaları da, diz ekleminde instabiliteye ve dolayısı ile kıkırdak dejenerasyonuna (osteoartrit) neden olabilen, özellikle sporcularda sık gelişen, önemli bir sağllk sorunudur. Reeves ve ark. ${ }^{82}$, proloterapi enjeksiyonları ile ÖÇB hasarı olan hastalarda stabilitenin sağlanarak kıkırdak dejenerasyonunun gelişiminin önlendiğini bildirmişlerdir.

ÖÇB yaralanmasının konservatif tedavisi için yapılan uygulamalarda sıklıkla diz çevresindeki kasların güçlendirilmesi ve bu şekilde ligament güçsüzlügünün kompanse edilmesi hedeflenmektedir. Ligamentin kendisinin güçlenmesi ise ancak cerrahi ile mümkün olmaktadır. Ancak, cerrahi sonrası ligament laksitesi tekrarlayabilmektedir ve sporcularda başarısız cerrahi sonrası spora dönüşün sağlanması oldukça güç olmaktadır. Ayrıca cerrahi tedaviden sonra uzun süren hareket kisitlamaları ve rehabilitasyon gereksinimi de bu yöntemin dezavantajlarındandır. Ön çapraz bağın kendisini güçlendiren bir diğer yöntem de proloterapi enjeksiyonlarıdır.

ÖÇB yaralanmalarında proloterapinin etkinliğinin araştırıldığı bir çalışmada, 6 aydan uzun süreli diz ağrısı olan ve ÖÇB laksitesinin eşlik ettiği 18 hastaya intraartiküler dektroz proloterapisi uygulanmış (iki ayda bir, 6 seans), 6 hasta çalışmayı tamamlayabilmiş, 6 . ayda 6 hastada, 12. ayda 9 hastada, 3. y1lda ise 10 hastada instabilitenin tamamen düzeldiği saptanmıştır. 3. Yıl değerlendirmesinde ayrıca hastaların ağrı ve fonksiyonel durumlarında da anlamlı düzelme saptanmıştır. ${ }^{83}$

Diz ekleminde tendon ve ligament yaralanmalarına bağlı gelişen patolojilerde mutlak cerrahi endikasyonu olmayan vakalarda proloterapi enjeksiyonları konservatif bir tedavi seçeneği sunmaktadır.

\section{Ayak Bileği ve Ayak Sorunlarında Proloterapi Enjeksiyonları}

Akut lateral ayak bileği instabiliteleri günlük hayatta sık görülen patolojilerdir ve iyi tedavi edilmediklerinde kronik fonksiyonel ve mekanik instabiliteye yol açabilirler. Ayak bileği yaralanmaları, her zaman basit yaralanmalar olmayıp hastaların \%20-40’ında kalıcı yakınmalara yol açmaktadır. Yetersiz tedavi gören hastalarda tekrarlayan travmalar kronik ayak bileği instabilitesine ve bunun sonucunda da erken "dejeneratif artroza "neden olabilmektedir.

Ayak bileği tendon ve ligament yaralanmalarının kronikleşmeden ve instabilite gelişmeden önce konservatif yöntemlerle tedavi edilmeleri tedaviye yanıtı hızlandırarak günlük yaşam aktivitelerine dönüş süresini kısaltmaktadır. Sporcularda uygun konservatif yöntemlerin erken dönemde başlanması spora dönüş sürecini anlamlı ölçüde kısaltmakta, aynı zamanda kronikleşme ve tekrarlayan yaralanma riskini en aza indirerek sporcu sağlığına önemli katkı sağlamaktadır.

Son dönem çalışmalarının sonuçları, lateral ligament hasarı olan olgularda konservatif tedaviyi desteklemektedir. Ayak bileği ligament yaralanmalarının \%80-90 kadarı, konservatif tedavi ile iyileşmektedir. Konservatif tedavi, erken dönemde kısaca RICE olarak bilinen istirahat, buz uygulama, kompresyon ve elevasyon uygulamaları ve sonrasinda uygulanan TENS, Ultrason gibi fizik tedavi modaliteleri ile egzersiz programını içermektedir. ${ }^{84}$ Ayak bileği tendon ve ligament yaralanmalası sonrasında konservatif tedavi uygulanan olgular normal günlük aktivitelere cerrahi tedavi uygulanan olgulara göre daha kısa sürede dönmektedirler.

Kronik ayak bileği instabilitesine yol açan nedenlerin başında lateral ligament relaksasyonu gelmektedir. Ayrıca 
subtalar instabilite, medial ligamentler ve sindesmoz yaralanmaları da nedenler arasındadır. Peroneal zayıflık da kronik ayak bileği instabilitesinin önemli nedenlerindendir.

Tendon ve ligament yaralanmalarında kronikleşme ve instabiliteye neden olan temel patolojik sürecin dejenerasyon olduğu göz önüne alındığında; dokularda doğal iyileşme sürecini tetikleyen ve bu nedenle de rejeneratif bir tedavi yöntemi olan proloterapi, ayak bileği ve ayak yaralanmalarında diğer bir konservatif tedavi seçeneğidir. Proloterapi enjeksiyonlarının, ayak ve ayak bileğinde tendon veya ligamanent patolojisi olan birçok vakada etkili olduğu gösterilmiştir. ${ }^{85}$

Kronik ayak bileği ağrısı yakınması olan ve ayak bileğinde ligament yaralanması, eklem instabilitesi ve osteoartrit tespit edilen 19 olguda, proloterapi uygulamalarının hastalarda ağrı ve tutukluk semptomlarını anlamlı ölçüde azalttığı ve yaşam kalitelerini arttırdığı bildirilmiştir. ${ }^{86}$

Rivello GJ ${ }^{87}$, kronik ayak, ayak bileği ağrısı olan hastaların proloterapi enjeksiyonlarını takiben, ortalama 2.5 yıllık takiplerinde ağrı yakınmalarında anlamlı azalma ve fonksiyonel iyileşme olduğunu bildirmiştir. Araştırmacı, çalışmaya dahil edilen ve öncesinde başka konservatif tedavilere yanıtsız kronik aşil tendinosisi veya lateral ligament, peroneal tendon yaralanmaları gibi patolojileri olan hastalarda proloterapiye yanıtın çok iyi olduğunu belirtmiştir. Aşil entesopatisi saptanan ve proloterapi enjeksiyonları uygulanan hastaların ağrı ve tutukluk yakınmalarında anlamlı azalma ile beraber günlük yaşam aktivitelerinde de belirgin iyileşme olmaktadır. Proloterapi, egzersiz programı ile kombine olarak uygulandığında iyileşme daha hızlı gerçekleşmektedir ${ }^{88}$.

Kronik aşil tendinozisi olan 36 hastada 6 haftada bir olmak üzere ortalama 4 seans uygulanan dekstroz proloterapi enjeksiyonları ile olguların istirahat halindeki VAS ağrı skorlarında \%88, normal günlük aktiviteleri esnasındaki VAS ağrı skorlarında \%84, spor veya diğer fiziksel aktiviteleri esnasındaki VAS ağrı skorlarında \%78 azalma saptandığı bildirilmiştir. ${ }^{89}$

Lyftogt $t^{90}$, aşil entesopatisi olan 16 hastada proloterapi enjeksiyonları sonrasında 14 hastada tam iyileşme sağlandığını ve hastaların yaralanma öncesindeki aktivitelerine döndüklerini bildirmiştir.

Aşil entesopatisi tanısı alan hastalarda proloterapi enjeksiyonları, ağrı ve tutukluk yakınmalarında azalmaya, günlük yaşam aktivitelerinde düzelmeye neden olduğu gibi, hasarlanmış tendonda olumlu yapısal değişikliklere de neden olmaktadır. Tedavi öncesinde ultrasonografide saptanan hipoekoik alanların yani hasarlanmış bölgelerin ve intratendinöz yırtıkların büyüklük ve şiddetinin proloterapi enjeksiyonları sonrasında azaldığı, tendon neovasküleritesinin ise arttığı bildirilmiştir. ${ }^{91}$

Plantar fasiit tanısı alan 60 hastada proloterapi enjeksiyonlarının etkinliğinin değerlendirildiği randomize kontrollü bir çalışmada, proloterapi enjeksiyonları uygulanan hasta grubunda, kontrol grubuna oranla 42, 90 ve 360. Günlerde VAS ağrı ve Foot and Ankle Outcome Score (FAOS) skorlarında anlamlı düzelme saptanmıştır. ${ }^{92}$ Ryan $\mathrm{MB}$ ve $\operatorname{ark}^{93}$, dekstroz proloterapi enjeksiyonları ile kronik plantar fasiit'li hastaların ağrı yakınmasında anlamlı azalma olduğunu bildirmişlerdir.

\section{Kalça Ağrısı ve Proloterapi}

Kronik kalça ağrısı oldukça sık gözlenen önemli bir halk sağlığı sorunudur ve kronik kalça ağrısı nedeniyle kalça eklemi artroplastisi uygulanan hasta sayısı giderek artmaktadır ${ }^{94}$. Kalça ekleminin normal kullanımında dahi eklem yapılarının yıpranması söz konusu olabilmektedir, çünkü kalça eklemi, günlük yaşam aktiviteleri sırasında çok fazla hareket eden ve zorlanan bir eklemdir ${ }^{95}$. Kalça artriti olan hastaları değerlendiren popülasyon çalışmaları gelecek yıllarda kalça artroplastisinin giderek artabileceğini öngörmektedir. ${ }^{96}$ Ancak, genellikle tatmin edici sonuçların 
olmaması, osteoliz, derin ven trombozu gibi risklerin olması, revizyon gereksinimi gibi nedenlerle total kalça protezi, bu hastalar için çok iyi bir seçenek değildir. ${ }^{97,98}$ Kronik kalça ağrısının geleneksel tedavi yöntemlerine sınırlı yanıt vermesi nedeniyle son dönemde hastalar alternatif tedavi yöntemlerine daha fazla yönelmeye başlamışlardır. Bu yöntemlerden birisi de proloterapi enjeksiyonlardır. ${ }^{99,100}$

Kronik kalça ağrısı olan hastaların çoğunda, ağrının nedenin kalça eklem kıkırdağındaki dejenerasyon olduğu düşünülmektedir. Kalça ekleminde kıkırdak dejenerasyonu gelişiminde majör risk faktörü eklemi stabilize eden yapıların (ligament, tendon, labrum) yaralanmalarıdır ve bu yapıların yaralanmasına bağlı gelişen kalça eklem dejenerasyonu daha çok tek taraflıdır. ${ }^{101}$

Esasen kalça eklemini destekleyen labrum, ligament ve tendonların hasarlanması kalça eklem patolojilerinde ve dolayısı ile kronik kalça ağrısı gelişiminde primer rol oynamaktadır. Labrum, tendon ve ligamentlerde oluşan doku hasarı bu yapılarda relaksasyona yol açmakta ve bunun sonucunda da eklem instabilitesi ve sonrasinda da eklem kıkırdak dejenerasyonu, koksartroz gibi kalça eklem patolojileri gelişmektedir. $\mathrm{Bu}$ nedenle diğer eklemlerde olduğu gibi birçok kalça eklem patolojisinde altta yatan nedeni tedavi etmeye yönelik uygulanan proloterapi enjeksiyonları kalça eklemi sorunlarına yaklaşımda önemli bir yer tutmaktadır. Kalça patolojilerinin replasman gerekecek kadar ilerlemesini beklemek yerine eklemin stabilitesini sağlayan tendon ve ligamentlerin güçlendirilmesi ve eklem kıkırdağının rejenerasyonu amaçlamak replasman gereksinimi azaltan doğru bir yaklaşım olacaktır. Proloterapi tekniği ile vücudun kendi iyileşme mekanizması tetiklenerek, enjeksiyonun uygulandığı bölgelerin güçlenmesi ve kalça ekleminin stabilitesinin sağlanması amaçlanır. Sonuç olarak kalça ekleminin daha akıcı hareketi, labrumun tamiri ve kıkırdak rejenerasyonu sağlanarak ağrının düzelmesi hedeflenir.

Labrum yırtığı saptanan 19 hastada dekstroz proloterapi enjeksiyonlarının etkinliğinin değerlendirildiği retrospektif bir çalışmada, 1-8 seans (ortalama 4.8) dekstroz proloterapisi uygulanmış olan hastalar tedavilerinin bitiminden 1-60 ay (ortalama 12 ay) sonra değerlendirilmiş ve tüm hastaların ağrı ve fonksiyonel durumlarında anlamlı iyileşme sağlandığı, hastaların \%54'ünde ağrı yakınmasının tamamen düzeldiği, tedavi sonrası takipte yan etki saptanmadığı ve bu sonuçların uzun dönem takiplerde de devam ettiği bildirilmiştir. ${ }^{102}$

Priformis sendromu da kalça ağrısının önemli bir nedenidir, bu sendromda ağrı tipik olarak kalçadan bacağa doğru yayılım gösterir. Etiyolojisinde sıklıkla tendon veya ligament relaksasyonu olan priformis sendromunun tedavisinde proloterapi enjeksiyonları etkili bir seçenektir. ${ }^{103}$

Sporcularda ve özellikle de futbolcularda sık gözlemlenen, kasık bölgesinde kronik ağrıya neden olan osteitis pubis sendromu da proloterapiye yanıt veren hastalıklardandır. Profesyonel sporcularda kasık ağrısı oldukça sık ortaya çıkan bir sağlık sorunudur. Futbol oyuncularında kasık ağrısının yıllık insidansı \%10-18 olarak bildirilmiştir. ${ }^{104}$ Atletlerde kronik kasık ağrısının en sık nedenleri osteitis pubis ve adduktor straindir. Topol ve ark.'nın ${ }^{105}$ yayınlamış oldukları bir vaka serisinde, pubik ramide bulunan hassas bölgelere yapılan çoklu enjeksiyonlar son derece başarılı bulunmuş; çoğu sporcu ağrılarından kurtulmuş ve tamama yakınının ortalama 9 hafta içerisinde spor yapmaya dönüşü sağlanmıştır.

Proloterapi enjeksiyonlarının kronik kalça ağrısı üzerinde etkinliğinin araştırıldığı bir çalışmada, kronik kalça ağrısı olan 61 hastaya dekstroz proloterapi enjeksiyonları uygulanmıştır. Hastalar son proloterapi enjeksiyonlarından sonra 19 ay boyunca takip edilmiş ve ağrı düzeyleri, günlük yaşam aktiviteleri ve fiziksel durumları ile ilgili sorgulanmışlar ve çalışmanın sonucunda; hastaların ortalama VAS ağrı skorlarının 7.0 düzeyinden 2.4 düzeyine gerilediği, ağrı yakınmasında \%50'den fazla azalma olan hastaların oranının \%89 olduğu, yürüme ve egzersiz aktivitelerinde 
\%84 oranında iyileşme olduğu ve \%54'ünün ağrı kesici almayı tamamen bıraktığı saptanmıştır. ${ }^{106}$

\section{Bel Ağrısı ve Proloterapi}

Bel ağrısı disabilite ve iş gücü kaybına neden olabilen önemli klinik, sosyal, ekonomik bir halk sağlığ1 sorunudur. Bel ağrısı yakınması olan hastalarda proloterapi enjeksiyonlarının bir tedavi yöntemi olarak kullanımı, lomber ve sakroiliak ligamentlerdeki yaralanmalara bağlı oluşan ligament relaksasyonunun instabiliteye neden olarak bel ağrısı yakınmasına yol açtığı düşüncesine dayanmaktadır. Bel ağrısı olan hastalarda proloterapi, genellikle egzersiz, vitamin ve mineral desteğini de içerecek şekilde uygulanmaktadir.

1987 yılında Ongley ve $\operatorname{ark}^{107}$ proloterapinin bel ağrısı üzerindeki etkilerinin araştırıldı̆̆ı ilk çalışmayı yayınlamışlardır. Bu çalışmada kronik bel ağrılı hastalara çalışma grubuna dekstroz, fenol, gliserin kontrol grubuna salin solüsyonu olmak üzere lomber bölge ligamentlerine ve apofiz eklem kapsüllerine haftada $1 \mathrm{kez}$ toplam 6 enjeksiyon uygulanmıștır. Ayrıca her iki gruba spinal manipülasyon uygulanmıştır. 6. Ayda çalışma grubunda ağrı ve disabilite VAS skorlarında anlamlı düzelme saptanmıştır. $\mathrm{Bu}$ çalışma kronik bel ağrısında proloterapinin etkinliğini değerlendiren ilk çalışma olması açısından değerli olmakla birlikte birçok kontrolsüz değişken içermektedir. Kontrol ve çalışma gruplarına farklı düzeylerde spinal manipülasyon uygulanmıştır. Tedavi grubuna enjeksiyonlar sırasında uygulanan \%0.25 Xylocaine kontrol grubuna uygulanmamıştır. Ayrıca, tedavi grubundaki hastalara triamcilone uygulanırken kontrol grubuna uygulanmamıştır. Bu nedenlere bağlı olarak bu çalışmada lokal anestezik madde ve steroid enjeksiyonları ile spinal manipülasyonun terapötik etki olasılıkları elemine edilememiştir. Sonuç olarak bu çalışmanın sonuçları, kronik bel ağrılı hastalarda proliferan madde, lokal anestezik ve steroid enjeksiyonlarının spinal manipülasyonla birlikte uygulanmasının ağrı ve disabilite üzerinde tek başına salin enjeksiyonu uygulamasına göre anlamlı üstünlüğü olduğunu göstermiştir.
Klein ve $\operatorname{ark}^{10}$, konservatif tedavilere ve laminektomiye rağmen yakınmaları devam eden kronik bel ağrılı 20 hastaya proloterapi enjeksiyonları ile birlikte spinal manipülasyon uygulamışlar ve lomber egzersiz programı vermişler. Tedavi sonrası değerlendirmede tedavi öncesine göre VAS ağrı ve disabilite skorlarında anlamlı düzelme saptandığını bildirmişlerdir.

Schwartz ve Sagedy ${ }^{108}$, cerrahi tedavi de dahil olmak üzere diğer tedavilere yanıtsız kronik bel ağrılı 43 hastaya posterior sakroiliak ligamentin fibro-osseöz bileşke bölgesine 2 hafta arayla toplam 3 kez proliferan solüsyon enjeksiyonu uygulamışlar. Enjeksiyonlar tamamlandıktan 2 hafta sonra hastaların üçte ikisinin ağrılarında \%66 azalma olduğunu rapor etmişlerdir.

$\mathrm{Bu}$ çalışmalarla birlikte, bel ağrısında proloterapi enjeksiyonlarının etkinliğini net olarak görmemizi sağlayacak kontrolsüz değişkenler içermeyen, randomize kontrollü, ileri çalışmalara ihtiyaç duyulmaktadır.

\section{Omuz Eklemi Sorunları ve Proloterapi}

Omuz eklemi instabilitesi, omuz ağrısının önemli ve sık bir nedenidir. Glenohumeral ligament laksitesi, glenoid labrumda superior labral anterior posterior (SLAP) yaralanma, impingement sendromu, akromioklavikular ayrılma gibi nedenlere bağlı olarak omuz ekleminde instabilite oluşabilmektedir.

Proloterapi enjeksiyonları ile omuz ekleminde gelişen tendon ve ligament yaralanmalarına bağlı instabilitenin önlenmesi veya tedavisi hedeflenmektedir.

Seven ve $\operatorname{ark}^{109}$, kronik rotator kuff lezyonu tanısı alan hastalarda rotator kuff tendonlarının omuz eklemindeki yapışma bölgelerine dekstroz proloterapi enjeksiyonları (ayda $1 \mathrm{kez}, 2-6$ seans) uygulamışlar ve proloterapi enjeksiyonları ile ağrı yakınmasında anlamlı azalma ile birlikte eklem hareket açıklığında ve fonksiyonel durumda anlam- 
lı artış olduğunu saptamışlardır.

\section{El Bileği ve El Sorunlarında Proloterapi}

El bileği ve interkarpal eklemler vücudun en karmaşık anatomisine ve biyomekaniğine sahiptir. El ve el bileğinde kırıkların dışında ağrı ve fonksiyon bozukluğu yapan başka nedenler de mevcuttur. Son yllarda bu bölgedeki ligamentlerin yaralanması sonucunda anatomik bütünlügün ve biyomekaniğin bozulduğu ve buna bağlı olarak el bileği fonksiyonlarının ağrılı bir şekilde zayıfladığı ortaya konulmuştur. ${ }^{110}$ Ayrıca ortaya çıkan anatomik ve biyomekanik bozukluğun el bileğinde ileri derecede dejeneratif artrite neden olduğu da gösterilmiştir. ${ }^{111} \mathrm{Bu}$ nedenle el bileği instabilitesi tanısının erken dönemde konulması ve erken tedavisinin yapılması çok önemlidir. Travmaya bağlı gelişen ligament yaralanmalarında prooterapi enjeksiyonları ile instabilitenin önlenmesi ve tedavisi hedeflenmektedir.

Hauser R ve ark ${ }^{12}$, kronik el bileği ağrısı yakınması olan hastalarda dekstroz proloterapi enjeksiyonlarından ortalama 22 ay sonrasında ağrı, depresyon ve anksiyete skorlarında ve ağrı kesici gereksiniminde anlamlı azalma, eklem hareket açıklığında anlamlı artış olduğunu bildirmişlerdir.

\section{Dirsek Eklemi Sorunları ve Proloterapi}

Dirsek eklemi yaralanmalarında ve kronik dirsek ağrısında eklemde instabilite oluşumunun önlenmesi tedavide önemli bir yer tutmaktadır. Dirsek ekleminin tam kat tendon ve ligament yırtıklarında cerrahi tedavi planlanırken kısmi yırtıklarda ve epikondilit, tendinit, tendinozis gibi sorunlarda öncelikle proloterapi gibi konservatif yöntemler uygulanmaktadır.

Kronik dirsek ağrısı toplumun \%15'ini etkileyen, sık gözlenen önemli bir sağlık sorunudur ${ }^{113}$, Dirsek ağrısının en sık nedeni olan lateral epikondilit, aynı zamanda dirsek ağrısı yakınması ile en sık hekime başvurma nedenidir. ${ }^{114}$

Dirsek ağrısı olan hastalarda NSAID'ler, Ultrason, cold/hot pack, TENS, ESWT gibi fizik tedavi modaliteleri, splintleme veya kortikosteroid enjeksiyonları sıklıkla uygulanan tedavilerdir. Ancak, bu konservatif tedavilerin dirsek ağrısı üzerindeki etkinliğini gösteren güçlü kanıtların olmaması bu yöntemlerin uygulanmasını tartı̧̧malı kılmaktadır. ${ }^{115}$ Geleneksel konservatif tedavilere yanitın sinırlı olması olması nedeniyle ${ }^{116,17}$ kronik dirsek ağrısı yakınması olan hastalarda proloterapi gibi alternatif yöntemler giderek daha sık uygulanmaktadır. ${ }^{118}$

Epikondilit, biseps tendiniti, dirsek osteoartriti, ligament spraini nedenleriyle kronik dirsek ağrısı yakınması olan ve proloterapi enjeksiyonu uygulanmıs olan hastaların sorgulandığı retrospektif bir çalışmada proloterapi enjeksiyonlarının ağrı ve tutukluk yakınmalarında anlamlı azalma ve yaşam kalitesinde artış sağladığı saptanmıştır. Dekstroz proloterapisi ile hastaların \%64'ünde ağrı skorlarında \%75'den fazla iyileşme kaydedilirken, hastaların \%94'ünde ağrı skorlarında \%50'den fazla iyileşme kaydedilmiştir. Hastaların yaşam kalitelerinde (eklem hareket açıklığı, depresyon, anksiyete, uyku, egzersiz yapabilme, ağrı kesici gereksinimi) anlamlı düzelmeler saptanmıştır. ${ }^{118}$

Dirsek ekleminin en sık gözlenen patolojisi olan lateral epikondilit, genel olarak inflamatuvar bir patoloji olarak değerlendirilmesine rağmen etiyolojisinde tendon hasarlanmasının yer aldığı, tendon iyileşme sürecinin sekteye uğraması ile gelişen anjiofibroblastik dejenerasyonun da eşlik ettiği bir durumdur ${ }^{119}$. Epikondilit sürecindeki ana patolojinin enflamatuvar değil de dejeneratif değişimler olduğu histolojik çalışmalarda gösterilmiştir. ${ }^{120-122}$ Proloterapinin epikondilit tedavisinde kullanımı, proliferan solüsyonların rejeneratif etkisi ile bu dejeneratif sürecin önlenebileceği veya tedavi edileceği düşüncesine dayanmaktadır.

Kronik lateral epikondilitli hastalarda, kortikosteroid ve proloterapi enjeksiyonlarının etkinliğinin karşılaştırmalı olarak incelendiği randomize kontrollü bir çalışmada VAS ile değerlendirilen hastaların ağrı yakınmalarının kortikosteroid ve proloterapi uygulanan her iki hasta grubunda başlangıçta anlamlı derecede azaldığı saptanmış, ancak, 6 . ay değerlendirmesinde kortikostroid grubunda aynı etki- 
nin devam etmediği, proloterapi grubunda ise VAS ağrı skorundaki anlamlı azalmanın devam ettiği kaydedilmiştir. $^{123}$

Proloterapinin lateral epikondilit üzerindeki etkinliğinin araştırıldığ 1 randomize, kontrollü bir çalışmada lateral epikondilit tanısı olan bir grup hastaya 0,4 ve 8 . haftalarda proloterapi enjeksiyonu uygulanırken kontrol grubuna saline enjeksiyonu uygulanmış, 6. hafta ağrı skorları değerlendirmesinde proloterapi grubunda başlangıca göre ve kontrol grubuna göre anlamlı düzelme saptanmıştır. Ayrıca proloterapi grubunda el bileği ekstansiyonu ve el kavrama kuvvetleri skorlarında da kontrol grubuna kıyasla anlamlı derecede düzelme kaydedilmiștir. Proloterapi grubundaki klinik iyileşmelerin 52 . Hafta değerlendirmesinde de devam ettiği belirtilmiştir. ${ }^{124}$

Shin JY ve ark ${ }^{125}$, lateral epikondilit tanisı olan 84 hastada proloterapi enjeksiyonlarını takiben 1. ve 3. Aylarda VAS ağrı skorlarının tedavi öncesi VAS skorlarına göre anlamlı olarak azaldığını bildirmişlerdir. Aynı çalışmada, ağrı skorlarındaki düzelmenin hastaların \%80.2'sinde 9. ay kontrolllerinde de devam ettiği belirtilmiştir.

Günümüzde proloterapi enjeksiyonları kas iskelet sistemi sorunlarında yaygın olarak kullanılan ve popülaritesi giderek artmakta olan konservatif bir tedavi yöntemidir. Proloterapi enjeksiyonlarının kas iskelet sistemi üzerindeki etkilerininin daha net bir şekilde ortaya konulabilmesi için daha fazla bilimsel çalışmaya gereksinim olduğu da bir gerçektir. 


\section{Kaynaklar}

1. Yelland MJ, Glasziou PP, Bogduk N, et al. Prolotherapy injections, saline injections, and exercises for chronic low-back pain: a randomized study. Spine. 2003;29:9-16.

2. Hackett, G.S., Hemwall, G.A., Montgomery, G.A. Ligament and Tendon Relaxation Treated by Prolotherapy. 5th edition. Oak Park (IL): Gustav A. Hemwall; 1993.

3. Schultz L. A treatment for subluxation of the temporomandibular joint. JAMA. 1937;25:1035-7.

4. Schultz L. Twenty years' experience in treating hypermobility of the temporomandibular joints. American Journal of Surgery. 1956;92: 925-928.

5. Loeser JD, Treede RD. The Kyoto protocol of IASP basic pain terminology. Pain 2008;137: 473-7.

6. Cailliet R: Soft tissue pain and disability, Philadelphia, FA Davis, 1997

7. HACKETT GS. Joint stabilization through induced ligament sclerosis. Ohio State Med J. 1953;49(10):877-84.

8. Liu YK, Tipton CM, Matthes RD, et al: An in situ study of the influence of a sclerosing solution in rabbit medial collateral ligaments and its junctional strength. Connec Tissue Res 1983;11:95- 102)

9. Maynard JA, Pedrini VA, Pedrini-Mille A, Romanus B, Ohlerking F. Morphological and biochemical effects of sodium morrhuate on tendons. J Orthop Res.1985;3(2):236-48.

10. Klein RG, Dorman TA, Johnson CE. Proliferant injections for low back pain: histologic changes of injected ligaments and objective measurements of lumbar spine mobility before and after treatment. J Neurol Orthop Med Surg 1989;10:141-144.

11. Meisenbach, R. O.: Sacro-Iliac Relaxation With Analysis of Eighty-four Cases. Surg., Gynec., \& 0bst. 1911;12:411-434.

12. Mengert, W.F. Referred pelvis pain especially due to sacroiliac relaxation or strain. South. M. J. 1943;36:256-263.

13. Magnuson, P.B. Differential diagnosis of causes of pain in the lower back accompanied by sciatic pain. Ann. Surg. 1944;119:878-891.

14. Newman, P. H.: Sprung back. J. Bone Jt Surg. 1952;34B:30-34

15. O'Connell JEA. Sciatica and the mechanism of the production on the clinical syndrome in protrusions of the intervertebral disc. Br J Surg. 1955;30:315.

16. G.S Hackett, M.D. Referred Pain from Low Back Ligament Disability. AMA Arch Surg. 1956;73(5):878-883.

17. James R, Kesturu G, Balian G, Chhabra AB. Tendon: biology, biomechanics, repair, growth factors, and evolving treatment options. J Hand Surg Am 2008;33:102-112.

18. Deie $M$, Sakamaki $Y$, Sumen $Y$, Urabe Y, Ikuta Y. Anterior knee laxity in young women varies with their menstrual cycle. Int Orthop. 2002;26:154-156.

19. Heitz NA. Hormonal changes throughout the menstrual cycle and increased anterior cruciate ligament laxity in females. J Athl Train. 1999;343:144-149.

20. Yu WD, Liu SH, Hatch JD, Panossian V, Finerman GA. Effect of estrogen on cellular metabolism of the human anterior cruciate ligament. Clin Orthop Relat Res. 1999;366:229-238.

21. Slauterbeck JR, Fuzie SF, Smith MP, et al. The menstrual cycle, sex hormones, and anterior cruciate ligament injury. J Athl Train. 2002;37:275-278.

22. Kannus P, Natri A. Etiology and pathophysiology of tendon ruptures in sports. Scand J Med Sci Sports 1997;7(2):107-112.

23. Harvie P, Ostlere SJ, Teh J, McNally EG, Clipsham K, Burston BJ, Pollard TC,Carr AJ. Genetic influences in the aetiology of tears of the rotator cuff.Sibling risk of a full-thickness tear. J Bone Joint Surg Br. 2004 Jul;86(5):696-700.

24. Flynn R K, Pedersen C L, Birmingham T B. et al The familial predisposition toward tearing the anterior cruciate ligament: a case control study. Am J Sports Med 20053323-28)

25. Child AH. Joint hypermobility syndrome: inherited disorder of collagen synthesis. J Rheumatol 1986; 13: 239-243.

26. Arendt Nielsen L, Svensson P. Referred muscle pain: basic and clinical findings. Clin J Pain. 2001;17: 11-19.

27. IASP. IASP Task Force on Taxonomy,. In: Merskey H, Bogduk N, editors. Classification of Chronic Pain. Second edition ed Seattle: IASP Press; 1994. pp. 209-214.

28. Longmire DR. The classification of pain and pain syndromes. Pain Digest 1992;2:229-233.

29. Józsa L, Kannus P. Histopathological findings in spontaneous tendon ruptures. Scand J Med Sci Sports. 1997;7(2):113-8.

30. Koob TJ, Clark PE, Hernandez DJ, Thurmond FA, Vogel KG. Compression loading in vitro regulates proteoglycans synthesis by tendon fibrocartilage. Arch Biochem Biophys 1992; 298:303-312.

31. Monaco JL, Lawrence T, Acute Wound Healing: An Overview. J Clin Plastic Surg 2003; 30: $1-12$.

32. Hanna JR, Giacopelli JA. A Review of Wound Healing and Wound Dressing Products. J Foot Ankle Surg 1997; 36: 2 - 14 .
33. Bujía J, Sittinger M, Wilmes E, Hammer C. Effect of growth factors on cell proliferation by human nasal septal chondrocytes cultured in monolayer. Acta Otolaryngol. 1994 Sep;114(5):539-43.

34. Dunham BP, Koch RJ. Basic fibroblast growth factor and insulinlike growth factor I support the growth of human septal chondrocytes in a serum-free environment. Arch Otolaryngol Head Neck Surg. 1998;124(12):1325-30.

35. Van Beuningen HM, Glansbeek HL, van der Kraan PM, van den Berg WB. Differential effects of local application of BMP-2 or TGF-beta 1 on both articular cartilage composition and osteophyte formation. Osteoarthritis Cartilage. 1998 ;6(5):306-17.

36. Wakitani S, Imoto K, Kimura T, Ochi T, Matsumoto K, Nakamura T. Hepatocyte growth factor facilitates cartilage repair. Full thickness articular cartilage defect studied in rabbit knees. Acta Orthop Scand. 1997;68(5):474-80.

37. Jensen $K$, et al. Response of knee ligaments to Prolotherapy in a rat injury model. American Journal of Sports Medicine. 2008;36:1347-1357.

38. Jensen $K$, et al. Early infammatory response of knee ligaments to Prolotherapy in a rat model. Journal of Orthopedic Research. 2008;26:816-823

39. Reeves $K$, et al. Evidenced-based regenerative injection (Prolotherapy) in sports medicine In Seidenberg P, Beutler A (eds.) The Sports Medicine Resource Manual. 2008; Saunders Publishing, Philadelphia PA, Chapter 50.

40. Natarajan $R$, et al. Vascular smooth muscle cells exhibit increased growth in respon se to elevated glucose. Biochemistry and Biophysic Research and Communication. 1992;186:552-560.

41. McGinn S, et al. High glucose and endothelial cell growth: novel effects independent of autocrine TGF-beta 1 and hyperosmolality. American Journal of Phyiology and Cell Physiology. 2003;234:C1374-C1386.

42. Caruccio $L$, et al. The heat-shock transcription factor HSF1 is rapidly activated by either hyper-or hypo-osmotic stress in mammalian cells. Journal of Biochemistry. 1997;327:341347.

43. Clarkson MR, Murphy M, Gupta S, Lambe T, Mackenzie HS, Godson C, Martin F, Brady HR. High glucose-altered gene expression in mesangial cells. Actin-regulatory protein gene expression is triggered by oxidative stress and cytoskeletal disassembly. J Biol Chem. 2002;277(12):9707-12.

44. Lam S, van der Geest RN, Verhagen NA, van Nieuwenhoven FA, Blom IE, Aten J, Goldschmeding $R$, Daha MR, van Kooten C. Connective tissue growth factor and igf-I are produced by human renal fibroblasts and cooperate in the induction of collagen production by high glucose. Diabetes. 2003;52(12):2975-83.

45. Di Paloa S, et al. High glucose concentration induces the overexpression of transforming growth factor-beta through the activation of a platelet-derived growth factor loop in human mesangial cells. American Journal of Pathology. 1996;149:2095-2106.

46. Fukuda $K$, et al. High concentration of glucose increases mitogenic responsiveness to heparin-binding epidermal growth factor-like growth factor in rat vascular smooth muscle cells. Arteriosclerosis Thombosis and Vasculature Biology. 1997;17:1962-1968.

47. Oh J, et al. Sequential effects of high glucose on mesangial cell transforming growth factor-beta 1 and fibronectin synthesis. Kidney International. 1998;54:1872-1878.

48. Murphy $M$, et al. Suppression subtractive hybridization identi es high glucose levels as a stimulus for expression of connective tissue growth factor and other genes in human mesangial cells. Journal of Biology and Chemistry. 1999;274:5830-5834.

49. Ohgi S, et al. Glucose modulates growth of gingival fibbroblasts and periodontal ligamen cells: correlation with expression of basic broblast growth factor. Journal of Periodontal Research. 1996;31:579-588.

50. Pugliese G, et al. Increased activity of the insulin-like growth factor system in mesangial cells cultured in high glucose conditions. Relation to glucose-enhanced extracellular matrix production. Diabetologia. 1996;39:775-784.

51. Reeves K. Prolotherapy: injection of growth factors or growth factor production stimulants to growth normal cells or tissue. In Waldman SD (ed): Pain Management. Philadelphia, Elsevier, 2006; 1106-1127.

52. Kim $\mathrm{H}$, et al. The effects of anti-inflammatory drugs on histologic findings of the experimental Prolotherapy model. Journal of the Korean Academy of Rehabilitation Medicine. 2006;30:378-384.

53. Ahn K, et al. The effect of the Prolotherapy on the injured Achilles tendon in a rat model. Journal of the Korean Academy of Rehabilitation Medicine. 2002;26:332-336.

54. Oh S, et al. Dextrose-induced subsynovial connective tissue fibrosis in the rabbit carpal tunnel: a protential model to study carpal tunnel syndrome. Hand. 2008;3:34-40.

55. Kim H, et al. Comparison of histological changes in accordance with the level of dextrose-concentration in experimental Prolotherapy model. Journal of Korean Academy of 
Rehabilitation Medicine. 2003;27:935-940.

56. Reinhold D, Ansorge S, Schleicher ED. Elevated glucose levels stimulate transforming growth factor-beta 1 (TGF-beta 1), suppress interleukin IL-2, IL-6 and IL-10 production and DNA synthesis in peripheral blood mononuclear cells. Horm Metab Res 1996;28:26770.

57. Jo, Daehyun, and Myounghee Kim. "The effects of Prolotherapy on knee joint pain due to ligament laxity." Journal of the Korean Pain Society 17.1 (2004): 47-50.

58. Hauser RA, Hauser MA. A Retrospective Study on Dextrose Prolotherapy for Unresolved Knee Pain at an Outpatient Charity Clinic in Rural Illinois. Journal of Prolotherapy. 2009;1:11-21.

59. Lohmander LS, Ostenberg A, Englund M, and Roos H. High prevalence of knee osteoarthritis, pain and functional limitations in female soccer players twelve years after anterior cruciate ligament injury. Arthritis \& Rheumatism. 2004; 50(10):3142-3152.

60. Panush R. Recreational activities and degenerative joint disease. Sports Medicine. 1994;17:1-5

61. Morehead K and Sack K. Osteoarthritis: What therapies for this disease of many causes? Postgraduate Medicine. November 2003. pp 12-17.

62. Rabago D, Patterson JJ, Mundt M, Kijowski R, Grettie J, Segal NA, Zgierska A. Dextrose prolotherapy for knee osteoarthritis: a randomized controlled trial. Ann. Fam Med. 2013;11(3):229-37.

63. Rabago D, Zgierska A, Fortney L. Hypertonic dextrose injections (Prolotherapy) for knee osteoarthritis: results of a single-arm uncontrolled study with 1-year follow-up.J Altern Complement Med. 2012;18(4):408-14.

64. Topol GA, Podesta LA, Reeves KD, Giraldo MM, Johnson LL, Grasso R, Jamín A, Clark T, Rabago D. Chondrogenic Effect of Intra-articular Hypertonic-Dextrose (Prolotherapy) in Severe Knee Osteoarthritis. PM R. 2016;8(11):1072-1082.

65. Rabago, David, et al. "Hypertonic dextrose injection (prolotherapy) for knee osteoarthritis: Long term outcomes." Complementary therapies in medicine 23.3 (2015): 388-395.

66. Rabago D, van Leuven L, Benes L, Fortney L, Slattengren A, Grettie J, Mundt M. Qualitative Assessment of Patients Receiving Prolotherapy for Knee Osteoarthritis in a Multimethod Study. J Altern Complement Med. 2016 ;22(12):983-989.

67. Eslamian F, Amouzandeh B. Therapeutic effects of prolotherapy with intra-articular dextrose injection in patients with moderate knee osteoarthritis: a single-arm study with 6 months follow up. Ther Adv Musculoskelet Dis. 2015;7(2):35-44.

68. Hassan F, Trebinjac S, Murrell WD, Maffulli N. The effectiveness of prolotherapy in treating knee osteoarthritis in adults: a systematic review. British medical bulletin. 2017;122(1):91-108.

69. Sit, Regina WS, et al. "Hypertonic dextrose injections (prolotherapy) in the treatment of symptomatic knee osteoarthritis: a systematic review and meta-analysis." Scientific reports 6 (2016): 25247.

70. Kim, Jong Moon. "The Effect of Prolotherapy for Osteoarthritis of the Knee." Journal of the Korean Academy of Rehabilitation Medicine 26.4 (2002): 445-448.

71. Reeves, Kenneth D., and Khatab Hassanein. "Randomized prospective double-blind placebo-controlled study of dextrose prolotherapy for knee osteoarthritis with or without ACL laxity." Alternative therapies in health and medicine 6.2 (2000): 68-80.

72. Lohmander LS, et al. The long-term consequences of anterior cruciate ligament and meniscal injuries: osteoarthritis. American Journal of Sports Medicine. 2007;35:1756-1769.

73. Bhargava $M M$, et al. The effect of cytokines on the proliferation and migration of bovine meniscal cells. The American Journal of Sports Medicine. 1999;27:636-643.

74. Spindler KP, et al. Regional mitogenic response of the meniscus to platelet-derived growth factor (PDGF-AB). Journal of Orthopaedic Research. 2005;13:201-207.

75. Murray MM, et al. Enhanced histologic repair in a central wound in the anterior cruciate ligament with a collagen-platelet-rich plasma scaffold. Journal of Orthopedic Research. \& Hashimoto J, et al. Meniscal repair using fibrin sealant and endothelial growth factor. The American Journal of Sports Medicine. 1992;20:537-541.

76. Reeves KD. Technique of Prolotherapy. In Lennard T. Physiatric Procedures in Clinical Practice. Philadelphia, PA: Hanely \& Belfus; 1995. p. 57-70.

77. Reeves KD. Prolotherapy: Basic Science, Clinical Studies, and Technique. In Lennard, T. Pain Procedures in Clinical Practice, Second Edition. Philadelphia, PA: Hanley \& Belfus; 2000. p. 172-190.

78. Okuda Y, et al. Increased production of PDGH by angiotensin and high glucose in human vascular endothelium. Life Sciences. 1996;59:455-461.

79. Kolm-Litty $V$, et al. High glucose-induced transforming growth factor beta 1 production is mediated by the hexosamine pathway in porcine glomerular mesangial cells. Journal of Clinical Investigation. 1998;101:160-169.

80. Liu X, et al. High glucose upregulates connective tissue growth factor expression in human vascular smooth muscle cells. BMC Cell Biology. 2007;8:1-14.

81. Hauser R. A Retrospective Study Shows Prolotherapy is Effective in the Treatment of MRI-Documented Meniscal Tears and Degeneration. Journal of Prolotherap. 2010;2(3):416-437.

82. Reeves KD and Hassanein K. Randomized prospective double-blind placebo-controlled study of dextrose prolotherapy for knee osteoarthritis with or without ACL laxity. Alternative Therapies. 2000; 6(2):68-80.

83. Reeves, K. Dean, and Khatab M. Hassanein. "Long-term effects of dextrose prolotherapy for anterior cruciate ligament laxity." Alternative therapies in health and medicine 9.3 (2003): 58-63.

84. Kirdemir Vecihi, Aslan A. Ankle Ligament injuries. Turkiye Klinikleri J Surg Med Sci 2007;3(39):22-7.

85. Tsatsos G, Mandal R. Prolotherapy in the treatment of foot problems. J Am Podiatr Med Assoc 2002;92:366-8.

86. Hauser RA, Hauser MA, Cukla J. Dextrose Prolotherapy injections for chronic ankle pain. Pract Pain Manag 2010: 70-76.

87. Rivello Gj. McGlamry's Comprehensive Textbook of Foot \& Ankle Surgery 4th Edition. Chapter 35, 181-86.

88. Yelland $M J$, et al. Prolotherapy injections and eccentric loading exercises for painful Achilles tendinosis: a randomised trial. Br J Sports Med 2011;45:421-8.

89. Maxwell NJ, Ryan MB, Taunton JE, et al. Sonographically guided intratendinous injection of hyperosmolar dextrose to treat chronic tendinosis of the Achilles tendon: a pilot study. AJR Am J Roentgenol 2007;189:W215-20.

90. Lyftogt J. Prolotherapy and Achilles tendinopathy: a prospective pilot study of an old treatment. Australasian Musculoskeletal Medicine. 2005;16-19.

91. Ryan M, Wong A, Taunton J. Favorable outcomes after sonographically guided intratendinous injection of hyperosmolar dextrose for chronic insertional and midportion achilles tendinosis. AJR Am J Roentgenol 2010;194:1047-53.

92. Ersen Ö, Koca K. A randomized-controlled trial of prolotherapy injections in the treatment of plantar fasciitis. Turk J Phys Med Rehab 2018;64(1):59-65.

93. Ryan $M B$, Wong $A D$, Gillies JH, Wong J, Taunton JE. Sonographically guided intratendinous injections of hyperosmolar dextrose/lidocaine: a pilot study for the treatment of chronic plantar fasciitis. Br J Sports Med. 2009 ;43(4):303-6.

94. Kurtz S. Prevalence of primary and revision total hip and knee arthroplasty in the United States from 1990 through 2002. J Bone Joint Surg Am. 2005 ;87(7):1487-97

95. Kim S. Changes in surgical loads and economic burden of hip and knee replacements in the US: 1997-2004. Arthritis Rheum. 2008;59(4):481-8.

96. Agency for Healthcare Research and Quality (AHRQ). Agency News and Notes: Musculoskeletal procedures account for over 10 percent of all hospital care in the United States.

97. Freedman KB. A meta-analysis of thromboembolic prophylaxis for elective total hip arthroplasty. Paper presented at: Ninth Annual Meeting of the American Association of Hip and Knee Surgeons; November 12-14,1999; Dallas, Texas.

98. Elfick A. Variation in the wear rate during the life of a total hip arthroplasty: A simulator and retrieval study. J Arthroplasty. 2000;379:34-40.

99. Alternative treatments: Dealing with chronic pain. Mayo Clinic Health Letter. April 2005. 23(4)

100. Lennard T. Pain Procedures in Clinical Practice. 2nd ed. Philadelphia, PA: Hanley \& Belfus, Inc.;2000.

101. Cyrus Cooper, Hazel Inskip; Individual Risk factors for Hip Osteoarthritis: Obesity, Hip Injury and Physical Activity, American Journal of Epidemiology, 1998;147(6): 516-52.

102. Hauser A, Orlofsky A. Regenerative Injection Therapy (Prolotherapy) for Hip Labrum Lesions:Rationale and Retrospective Study. The Open Rehabilitation Journal, 2013; 6:59-68.

103. JW, Norbury. Diagnosis and Management of priformis syndrome. Practical Neurology May 2012.

104. Holmich P, Uhrskou P, Ulnits L, et al. Effectiveness of active physical training as treatment for long-standing adductor-related groin pain in athletes; randomized trial. Lancet 1999;353:439-43.

105. Topol GA, Reeves KD, Hassanein KM. Efficacy of dextrose prolotherapy in elite male kicking-sport athletes with chronic groin pain. Arch Phys Med Rehabil 2005;86:697-702.

106. Hauser A. A Retrospective Study on Hackett-Hemwall Dextrose Prolotherapy for Chronic Hip Pain at an Outpatient Charity Clinic in Rural Illinois. Journal of Prolotherapy. 2009;2:76-88.

107. Ongley MJ, Klein RG, Dorman TA, Eck BC. A new approach to the treatment of chronic low back pain. Lancet 1987;2:143-146

108. Robert G. Schwartz, M.D. and Noreen Sagedy, M.D. Prolotherapy: A Literature Review and Retrospective Study. The Journal of Neurological and Orthopadic Medicine and Sur- 
gery, 1991;12(3)

109. Seven MM, Ersen O, Akpancar S, Ozkan H, Turkkan S, Yildiz Y, Koca K. Effectiveness of prolotherapy in the treatment of chronic rotator cuff lesions.Orthop Traumatol Surg Res. 2017;103(3):427-433

110. Koca K, Kürklü M. Karpal instabilitelerin radyolojik değerlendirilmesi. TOTBID Dergisi 2013;12(1):47-53.

111. Pilný J, Svarc A, Hoza P, Vodicka Z, Krbec M. [Arthritis development following untreated scapholunate instability of the wrist]. Acta Chir Orthop Traumatol Cech. 2010 ;77(2):1313.

112. Hauser R, Hauser M, Holian P. Dextrose prolotherapy for unresolved wrist pain. Practical Pain Management. 2009:72-79

113. O'Connor F. Managing overuse injuries. A sys- tematic approach. The Physician and Sports Medi- cine. 1997. 25: 88-113.

114. Pecar D and Avdic D. Efficacy of tennis elbow (Epicondylitis humeri radialis) treatment in CBR "Praxis." Bosn J Med Sci. 2009;9(1): 25-30

115. Pecar D and Avdic D. Efficacy of tennis elbow (Epicondylitis humeri radialis) treatment in CBR "Praxis." Bosn J Med Sci. 2009; 9(1): 25-30

116. Alternative treatments: Dealing with chronic pain. Mayo Clinic Health Letter. April 2005. 23(4).

117. Lennard, T. Pain Procedures in Clinical Practice. Second Edition. Hanley \& Belfus, Inc. Philadelphia, PA. 2000.

118. Hauser R, Hauser M, Holian P. Dextrose prolotherapy for unresolved wrist pain. Practical Pain Management. 2009;Nov/Dec:72-79.

119. Jobe F, Ciccotti M. Lateral and medial epicondylitis of the elbow. J Am Acad Orthop Surg 1994;2:1-8.

120. Allman F, Nirschl R, Plagenhoef S, et al. Tennis elbow: Who's most likely to get it and how. Physician Sports Med 1975;3:43-58.

121. Leach R, Miller J. Lateral and medial epicondylitis of the elbow. Clin Sports Med 1987;6:5972

122. Nirschl R. Soft tissue injuries about the elbow. Clin Sports Med 1985; 5:637-652.

123. Carayannopoulos A, Borg-Stein J, Sokolof J, Meleger A, Rosenberg D. Prolotherapy versus corticosteroid injections for the treatment of lateral epicondylosis: a randomized controlled trial. PM R. 2011;3(8):706-15.

124. Scarpone M, Rabago D, Arbogest J, Snell E, Zgierska A. The efficacy of prolotherapy for lateral epicondylosis: A pilot study. Clin J Sports Med 2008;18:248-254.

125. Shin J, Seo K-M, Kim D-K, Kim B-K, Kang S-H. The effect of prolotherapy on lateral epicondylitis of elbow. I Korean Acad Rehabil Med. 2002;26:764-8. 